\title{
Unhealthy Neighbourhood "Syndrome": A Useful Label for Analysing and Providing Advice on Urban Design Decision-Making?
}

\author{
Husam AlWaer ${ }^{1, *(\mathbb{D}}$, Joshua Speedie ${ }^{1}$ and Ian Cooper ${ }^{2}(\mathbb{D}$ \\ 1 School of Social Sciences (Architecture \& Urban Planning), University of Dundee, Dundee DD1 4HN, UK; \\ js@designoutsider.com \\ 2 Eclipse Research, Cambridge CB4 2JD, UK; ian.cooper@eclipseresearch.co.uk \\ * Correspondence: h.alwaer@dundee.ac.uk
}

Citation: AlWaer, H.; Speedie, J.; Cooper, I. Unhealthy Neighbourhood "Syndrome": A Useful Label for Analysing and Providing Advice on Urban Design Decision-Making? Sustainability 2021, 13, 6232. https://doi.org/10.3390/su13116232

Academic Editors: Paola Sassi, John Brennan and Mina Samangooei

Received: 13 February 2021

Accepted: 26 May 2021

Published: 1 June 2021

Publisher's Note: MDPI stays neutral with regard to jurisdictional claims in published maps and institutional affiliations.

Copyright: () 2021 by the authors. Licensee MDPI, Basel, Switzerland. This article is an open access article distributed under the terms and conditions of the Creative Commons Attribution (CC BY) license (https:// creativecommons.org/licenses/by/ $4.0 /)$.

\begin{abstract}
Even before the COVID-19 pandemic, there was growing interest in designing healthier neighbourhoods. Adopting this perspective brings attention to how conditions in neighbourhoods (directly and indirectly) affect their inhabitants' physical health and mental wellbeing. However, considerably less attention has been paid to how to alleviate such conditions through integrated interventions designed to operate specifically at the neighbourhood scale. To address this gap, this paper introduces the term "unhealthy neighbourhood syndrome" (UNS). The conceptual clarity and practical utility offered by using this term are critically examined. The paper contains a rigorous review and critical analysis of academic and grey literature on what are held to be the relationships between key features of the built environment and people's health and wellbeing. It also examines literature offering advice on how urban designers should make neighbourhoods healthier. It illustrates the complexity of the range of issues involved and the complicated web of top down, bottom up and middling out actors that need to be involved in making decisions about them. Despite having inherent weaknesses, the term "unhealthy neighbourhood syndrome" is judged to be useful. It illustrates how seemingly separate issues operate in urban design, promoted for tackling specific symptoms of ill health, need to be addressed jointly through an integrated programme of parallel work streams operating at the neighbourhood scale. The paper is innovative in identifying the wide cluster of symptoms used to describe unhealthy neighbourhoods in the literature as being a "syndrome". Its significance lies in its injunction that this syndrome needs to be tackled through integrated streams of remedial action drawing on experience and expertise that lie beyond those offered by the traditional membership of urban design teams.
\end{abstract}

Keywords: unhealthy neighbourhood syndrome (UNS); healthy built environments; neighbourhood; healthy neighbourhood; health and wellbeing; mitigating; symptoms; multi-disciplinary teamwork

\section{Introduction}

Concepts like neighbourhood planning [1], healthy place making [2-6], healthy building [7], the just city [8], sustainable neighbourhood [9], and the city of wellbeing [10] have gained traction since the early 2000s. Such notions are regarded as having become "accepted components of planning" [11]. These concepts are all fundamentally premised on the need to redress unfair, unequal, unhealthy and inequitable urban societies. In practice, attitudes to health and health inequalities are beginning to change, both within government and society, with a shift away from the idea that a flourishing life is primarily connected to material prosperity towards one that positions wellbeing and health as significant goals for public policy [2,12]. This move is being accompanied by a wide range of commitments for the design of a healthy environment that would have a positive effect on: (a) physical health and mental wellbeing, (b) safeguard ecological integrity, (c) promote greater equity, tackling inequalities in health, and (d) support more healthier places in the low 
carbon future $[13,14]$. Despite existing evidence of the direct and indirect effect of the built environment on health and wellbeing [10], there are continued calls for even greater evidence-based research to further unpack this complex relationship at the neighbourhood level [15-18]. Additionally, in response to the recent COVID-19 pandemic, there has been an explicit recommendation to "further understand the links between neighbourhood design and health" [19] (p. 9). Clear evidence that makes the connection between the built environment (within the discourses of planning and urban design) and health/ill health is seen as being required to guide built environment professionals and policy makers towards positive change [20-22].

As stressed by the Royal Town Planning Institute [23], "there is a real need to 'move the debate forward' and to translate (the many) principles of healthy built environment into practice" (p. 6). Unless there is explicit articulation of what contributes to healthiness of neighbour and of urban design strategies for its promotion, there is a risk of creating misunderstanding and barriers to communication across different organizations, stakeholder groups and actors involved. A lack of clarity can also undermine trust and confidence, leading ultimately to opposition to both the urban design process and to its outcomes. However, the number of studies directly focused on attempting to identify the unhealthy characteristics (symptoms) of neighbourhoods is limited and fragmented. This paper investigates the term "unhealthy neighbourhood syndrome" (UNS). The value of using this label for advancing conversation around urban design and planning to support health and wellbeing is explored. Four overarching questions are investigated.

(1) Is "the neighbourhood" a useful (spatial) category for analysing, organising and offering advice to urban designers?

(2) If so, is it reasonable to describe a neighbourhood as "healthy" or "unhealthy"?

(3) What is the advantage of labelling the phenomenon of unhealthy neighbourhoods as a "syndrome"?

(4) Additionally, if UNS is a useful diagnostic label for providing advice, what strategies can be adopted to mitigate the symptoms it is used to diagnose?

Grappling with these questions is timely given the importance being attached to health in general-and to healthy neighbourhoods in particular-by governments, local authorities, professional institutions, and private sector organisations worldwide, not least because of the COVID-19 pandemic (e.g., Public Health England 2020a [24]).

\section{Research Design}

This paper is focused on urban design specifically at the neighbourhood scale. It offers new, extensive, detailed and systematic examinations of two types of literature on the relationships between health and urban design at that scale: (a) how urban design affects health, primarily at the neighbourhood scale and (b) what urban designers should do to make neighbourhoods healthier. Both of these literatures are primarily aimed at a minor part of decision making about urban design in developed countries-making the design of new neighbourhoods healthy. This paper is addressed to examining the larger part of such decision-making-remedial action in existing neighbourhoods which are deemed unhealthy. The term UNS will be used as a lens through which to critically review what are held to be the contributors to and the mitigators of threats to neighbourhood residents' and visitors' physical health and mental wellbeing. UNS is investigated as a useful label, not just for synthesizing and collating evidence about the features of neighbourhood urban design that contribute to poor health and wellbeing, but also to signpost a path towards those elements of urban design that can contribute to their mitigation. It is beyond the scope of this short paper to investigate all the elements that have been deemed significance. However, while not claiming to be comprehensive, the purpose here is to make explicit a set of weaknesses, challenges, limitations, and potentials of neighbourhood urban design - as identified from the large body of existing literature reviewed-that can be used to contribute to the ongoing conversation about how to employ urban design to make neighbourhoods healthier. 
In this paper, human health and wellbeing are conceptualised broadly. While we begin with an investigation of how urban design is seen as contributing to poor physical health and mental wellbeing, we acknowledge that wellbeing is also about human resilience and flourishing - not just the absence of injury or disease [25]. Such flourishing depends on social interaction with others. Individual health and wellbeing can be supported not only by 'a healthy mind in a healthy body' (from Juvenal's Satire X), but by a developed network of social relationships which help to bring about a healthy neighbourhood. Conversely, an unhealthy neighbourhood not only consists of individuals with poor physical and mental health, but a deterioration of both the neighbourhood's social and physical fabric that makes "neighbourliness" (and social interaction need to support this) less likely and more difficult to achieve.

\section{Scope and Focus of Attention}

This paper is based on two extensive reviews of published literature on (a) how the built environment affects health, primarily at the neighbourhood scale and (b) what urban designers should do to respond to what is currently known about this relationship. What are said to be the symptoms displayed by unhealthy neighbourhoods were collated and critically analysed through a systematic review [26], initially using a "title/abstract/keyword" search method. The keywords used in the literature search included "healthy neighbourhoods", "unhealthy neighbourhoods", "neighbourhood problems", "health communities", "unhealthy communities", "community problems", "symptoms" and "illness", supplemented by the phrases "health and urban design", "wellbeing and urban design". Searches were made using the Web of Science, Google Scholar, Scopus, ProQuest, ACM digital library and ScienceDirect. In addition, grey literature was also searched to identify resources intended to support urban planning and design practice. This twin-headed approach allowed systematic exploration of the existing literature and identification of gaps in what is available in the public domain. Relevant academic and grey literature was collated and interrogated. An ancestry search was used to review the bibliographies found in these publications to expand the sources reviewed. The purpose of the review was to identify how the design of neighbourhoods is portrayed as contributing to good/ill health and to collate what is offered as evidence of how this can be mitigated or improved.

The purpose of the two content analyses presented below was (a) to construct an analytic framework that would help clarify the boundary and constituent elements of UNS and so (b) enable a critical analysis of the utility of this label for providing guidance on urban design. Sources identified for inclusion in the study were identified, collated, investigated, and coded. Relevant material from each publication was recorded into a spreadsheet, where each column was used to capture information about a discrete theme or issue. Efforts were made to identify what were presented as both negative and positive elements of urban design at the neighbourhood scale that have effects on health and wellbeing. There were limitations to such an approach. The term "neighbourhood" includes, but is not limited to, a geographical location, nor does it describe a uniform or discrete set of socio-economic, physical, or environmental variables. As a result, this paper is not an attempt to produce a generic set of neighbourhood problems, as each neighbour necessarily has its own distinct characteristics, and its own mix of what works well or badly. Even within a particular neighbourhood, those who live or work there are not homogeneous. Instead, they are individuals and groups with varied interests in, differing levels of knowledge about, and engagement with, their neighbourhood-accompanied by differing health and wellbeing needs, as well as varied expectations and aspirations about what their neighbourhood can and should provide.

This paper is structured into two parts. The first part reviews academic literature on how aspects of the built environment, considered at the neighbourhood scale, affect people's physical health and wellbeing. The second part reviews what the academic and grey literature says about how urban design can be manipulated to mitigate those aspects 
of the built environment which are held to adversely affect physical health and wellbeing. The discussion considers the clarion call that has been made for a more integrated, interdisciplinary approach to designing healthy neighbourhoods.

\section{Part One: How the Built Environment Is Held to Affect Physical Health and Wellbeing at the Neighbourhood Scale}

\subsection{What Is Meant by "Neighbourhood" and by "Health and Wellbeing"?}

One of the first problems that needs to be addressed is what is meant by the term "neighbourhood". As used in the literature reviewed, this is a multifarious concept: there is no simple, consensus answer to "what is a neighbourhood" $[27,28]$. There are, however, two main approaches to identifying a neighbourhood: (1) through administrative geography, and (2) through subjective identification. This difference can be traced to disciplinary backgrounds, with the social sciences emphasizing the human realm and concern for physical planning, with its roots in architecture emphasizing the built realm [29] (p. 363). Boundaries designating what is in and outside a neighbourhood can often contradict one another. As Guise and Webb noted [30], "neighbourhoods are usually fuzzily defined, with different people having different views on the boundaries of the area" (p. 8). They cautioned that "administratively delineated neighbourhoods, parishes, or quarters, may or may not coincide with neighbourhoods as perceived by the residents" (ibid.). To illustrate the complexity of this concept, Table 1 illustrates how the treatment of it has changed over the last three quarters of a century.

Table 1. Designations of "neighbourhood" listed chronologically to show how ideas have shifted over time.

\begin{tabular}{|c|c|}
\hline Mumford [31] & $\begin{array}{l}\text { "neighbourhoods, in some annoying, inchoate fashion exist wherever human } \\
\text { beings congregate, in permanent family dwellings; and many of the functions } \\
\text { of the city tend to be distributed naturally-that is, without any theoretical } \\
\text { preoccupation or political direction-into neighbourhoods" (p. 258). }\end{array}$ \\
\hline Jacobs [32] & $\begin{array}{l}\text { Neighbourhoods can be defined at three levels of geographic and political } \\
\text { organization: the street level, district level, and city-level. }\end{array}$ \\
\hline Lynch [33] & $\begin{array}{l}\text { Unit of social analysis } \\
\text { Territorial base of socially supportive group } \\
\text { Defined spatial unit } \\
\text { Catchment of services, elementary school }\end{array}$ \\
\hline The Urban Task Force [34] & $\begin{array}{l}\text { By itself, housing does not make a neighbourhood. Neighbourhoods need to } \\
\text { comprise a mix of uses which work together to encourage formal and informal } \\
\text { transactions, sustaining activity throughout the day. The mixing of different } \\
\text { activities within an area should serve to strengthen social integration and } \\
\text { civic life. }\end{array}$ \\
\hline Galster [35] Lupton and Power [27] & $\begin{array}{l}\text { Attributes of neighbourhoods-from geographic to social } \\
\text { Environmental-topography, pollution } \\
\text { Proximity-location, transport infrastructure } \\
\text { Buildings-type, design, material, density, repair } \\
\text { Infrastructure-roads, streetscape } \\
\text { Demography-age profile, class status, ethnic diversity, mobility of population } \\
\text { Existence and quality of local services } \\
\text { Social-interactive-friend and family networks, } \\
\text { local associations, informal interactions, social control mechanisms } \\
\text { Sentiment-identification with place, historical significance, local stories } \\
\text { Political-local parties, political networks, resident involvement }\end{array}$ \\
\hline The Young Foundation [28] Barton and Hills [36] & $\begin{array}{l}\text { Neighbourhoods are ultra-local communities of place. Most people feel that } \\
\text { they intuitively understand what they mean, in the shape of neighbourly } \\
\text { interactions, mutual support, gathering places and a friendly, } \\
\text { attractive environment-or in a "bad neighbourhood", danger, } \\
\text { anti-social interaction, exclusiveness, isolation and dereliction. Local service } \\
\text { catchments areas, based on walking distance. }\end{array}$ \\
\hline
\end{tabular}


Table 1. Cont.

\begin{abstract}
A spatial unit that people relate to.
A neighbourhood is often conceptualized around three dimensions: size/shape: defined through the types of edges that provide boundaries.

The edges can be human-made or natural and be different in character or type. public space, or commercial uses.

Morphology: The pattern of streets, blocks, lots, and buildings. Such patterns can have a significant effect on neighbourhood quality, character, and functionality.
\end{abstract}

Talen [29] Function: characterized by the location of functions, such as civic buildings,

A starting point for identifying the neighbourhood structure of a settlement is to locate the sub-centres and repeating pattens of associated uses. For example,

Kropf [37] retail, education, worship, community and recreational facilities can constitute sub-centres and may correlate with the more loosely defined and socially based unit of the neighbourhood.

"neighbourhood is a state of being in a relationship. More than anything, the human environment is about relationships: relationships between people and planet, relationships between people and place, and relationships between people and people" (p. 37).

As Table 1 indicates, neighbourhoods can be conceptualized as a physical place or a social construction or, simultaneously, both. Thus, the notion of neighbourhoods lacks the categorical discreteness necessary for analytical exactitude. In this paper, we also differentiate between two related categories- "neighbourhood" as a socio-physical geographical, location and "neighbourliness", as a descriptor of a particular pattern of social relations-exhibiting a disposition to be friendly and helpful to neighbours. The latter is not an unexceptional extension of the former. People can live in a neighbourhood (and thus be neighbours) without exhibiting neighbourliness. Indeed, "neighbourliness" can, and is taken to be, see below, an indicator of an "healthy" neighbourhood-a designation that extends well beyond solely physical considerations. Accordingly, in this paper, our working definition of a "neighbourhood" is that it is an ill-defined socio-physical construct that seeks to map what may be an amorphous spatial area containing possibly diverse sets of occupants-who may or may not perceive themselves as constituting a socially defined unit aligned with the designated spatial area.

There is also no simple, consensus answer to what is meant by "health" and "wellbeing" in urban design literature. This seldom offers specific definitions when these two terms are used. Instead, they are left undefined and so ambiguous. However, the quality of urban design is explicitly presented as having either positive or negative effects on them $[23,39,40]$. For example, London [6] highlighting the need to maintain normal blood pressure for robust lung function and for unclogged arteries, mandated that the built environment should deliver clean air and encourage physical activity. Additionally, recognising the need to avert anxiety and depression, he also identified a role for the built environment in life satisfaction, by delivering happiness, inspiration, social connectedness, and spiritual fulfilment. Indeed, the measure of a good building-or, by extension, a good neighbourhood or a good city - is held to be the extent to which it moves its occupants towards these broad, aspirational outcomes (ibid). However, as Pineo and Rydin [12] explained, different neighbourhoods may have very different access to opportunities (distribution of power, money and resources), which can negatively or positively affect health. They identified that poorer neighbourhoods are more likely to have low quality housing, greater exposure to pollution and reduced access to key services-resulting in inequalities in the distribution of physical health and mental wellbeing (ibid. p. 8).

In this paper, the term "health" is used to refer to "physical health" and "wellbeing" is restricted to referring to "mental wellbeing". However, this convention is not strictly followed in the literature reviewed. There, the terms health and wellbeing are employed as if synonymous or as an extension of one another. Where this happens, the specific 
relationship between each of them and neighbourhood design cannot be disaggregated. Despite this, focusing on the healthiness of a neighbourhood is held out as promising to help identify design decisions that may themselves negatively affect its residents. Additionally, from an urban design perspective, adopting such a framing can help highlight that those who live in "unhealthy neighbourhoods" are not only economically and socially exploited, but may be spatially oppressed, confined to living in degraded and degrading environments. This spatial component of disadvantage is neither universal recognised nor considered. For example, the Institute of Fiscal Studies' ongoing study of inequalities in the UK [41], does not use "the neighbourhood" as a unit of analysis. This is despite the study being funded by the Nuffield Foundation — an independent body whose mission is to advance social wellbeing. Such an omission suggests that, even now, this specific level of spatial effect can remain neglected. This paper is focused on why neighbourhoods are important and why they need to be brought to the fore. The importance of doing so is evidenced by Nordic countries, where it is worth noting the coincidence of their low levels of social inequality and what is deemed to be their excellence in urban design [42].

\section{2. "Problem" Neighbourhoods}

The causes of neighbourhood "problems" are the subject of much debate within urban design, but also in the fields of health, economics and sociology. For instance, just within public health literature, neighbourhood problems are frequently described as being influenced by (1) neighbourhood disadvantage, (2) neighbourhood decline, and (3) neighbourhood disorder [43,44].

Neighbourhood Disadvantage has been used to describe a neighbourhood that lacks economic, infrastructure and social resources. Ross and Mirowsky [43] characterised disadvantage as taking two forms: physical and social. They described physical disorder as "signalled by abandoned buildings, noise, graffiti, vandalism, filth, and disrepair; and social disorder by crime, loitering, public drinking or drug use" (p. 258). A disadvantaged neighbourhood can threaten the physical and mental health of its residents $[43,45,46]$. According to Ross and Mirowsky [43] "the effect of living in a disadvantaged neighbourhood on physical wellbeing is mediated entirely by disorder in the neighbourhood, which influences health both directly and indirectly, by way of fear" (p. 272).

Neighbourhood Disorder is marked by exposure to observable cues that social control has broken down in a neighbourhood (e.g., vandalism, abandoned and rundown buildings, drug use), creating a sense of danger. Repeated exposure to neighbourhood disorder can induce stress and impair health $[43,47]$. It can also influence residents to make unhealthy decisions, like avoiding healthful outdoor activities, such as walking [48,49]. Continued exposure to neighbourhood disorder "may stimulate frequent terror and chronic foreboding, repeatedly flooding the body with adrenal hormones that directly undermine health" [45] (p. 258). Curtice et al. [50] described "incivilities" as another important element affecting health and wellbeing. They suggested that those who experienced greater incivilities reported higher levels of poor health, depression and anxiety. Their presence also contributes to greater fear of crime and a decrease in trust. Research has reportedly suggested that: (a) residents of disorderly neighbourhoods feel less safe, independent of ethnic make-up [51]; (b) report lower levels of trust [43]; and (c) are less satisfied with their neighbourhood [52].

Neighbourhood Decline has been conceptualized as both a degradation of the housing stock and decline of household income [44]. Zwiers et al. [53] used a broader definition to include "any negative development in the physical, demographic, or socioeconomic conditions of a neighbourhood as experienced by its residents or other stakeholders" (p. 656).

These three terms-neighbourhood disadvantage, disorder, and decline- -have all been used to underscore how local circumstances affect physical health and mental wellbeing. They each signpost both objective and subjective features of the built environment. These three classifications point to different factors in the built and social environment 
that can affect a neighbourhood, giving rise to, and then reinforcing patterns of, inequality which, in turn, directly and indirectly affect human health and wellbeing. The complexity they portray suggests that neighbourhood unhealthiness defies a clear definition, has overlapping and countervailing elements, concerns a multiplicity of stakeholder views, and is difficult to solve [54]. It also lacks an easily tackled system boundary. This complexity is compounded by deeper systemic social problems, such as structural poverty and inequality [55]. Additionally, even if conditions can be improved within a particular neighbourhood, targeting it for intervention can "hold an ever-present risk of the pathologization of the poverty problem" [56] (p. 63).

\subsection{The Depiction of the Health Effects of the Built and Natural Environments}

By now it should be clear that the relationship depicted between health and neighbourhoods is complex. While many physical health symptoms, related to environmental exposures [16,57], are readily measurable, those that contribute to mental health can be challenging to quantify. Many are intangible elements that can have interconnections to both short- and long-term effects. Multiple models have been constructed that seek to illustrate this complexity. Few of these are confined to health and wellbeing at the neighbourhood scale. However, since UNS can be influenced by both strategic and local decisions about urban design, existing models that seek to identify the health effects of the built and natural environment at a variety of scales can be useful for considering what is within and beyond the scope of neighbour design. As Barton [10] warned, "at each of these stages [of decision-making] there are other forces at work which affect outcomes, and often these have more importance than planning and design. Therefore, due humility is appropriate on the part of planners, while also accepting their core responsibility for ensuring a healthy environment" (p. 92). Even if planning and urban design decisions are made at the strategic and local level to enhance health and wellbeing, these decisions do not guarantee the physical health and mental wellbeing of residents, since the influence of such decisions is mediated through environmental, lifestyle, and personal experiences (among others), which may operate at the neighbourhood scale. One of the most widely referenced models for depicting the main determinants of health is Whitehead and Dahlgren's (1991) Rainbow Model [58], see Figure 1.

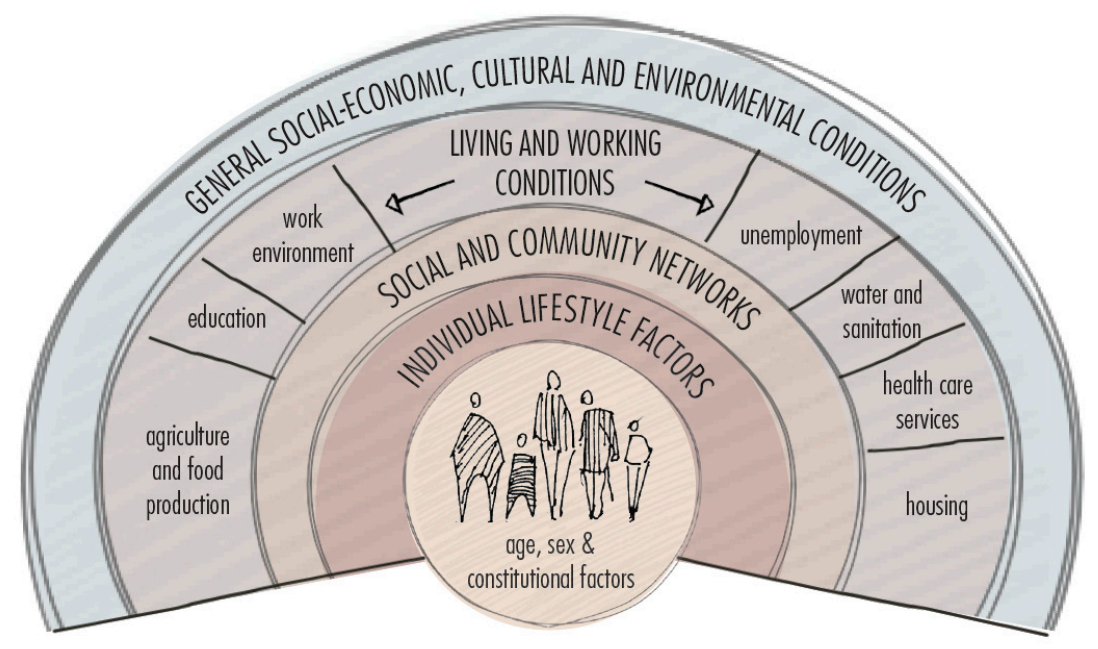

Figure 1. Rainbow Model (Source: Dahlgren and Whitehead 1991).

This recognizes broad societal level factors (such as general socio-economic, cultural, and environmental conditions) through proximal (individual lifestyle) and distal (living and working) conditions. The model was used to underpin the WHO's Commission on the Social Determinants of Health [59]. The key message of that report was that direct and indirect determinants of health are social in origin-a result of social decisions taken by individuals and organisations and by society at large. Building on Whitehead and Dahlgren's 
Rainbow Model, Barton and Grant [14] developed their Health Map, see Figure 2, using systems theory and the principles of sustainable development.

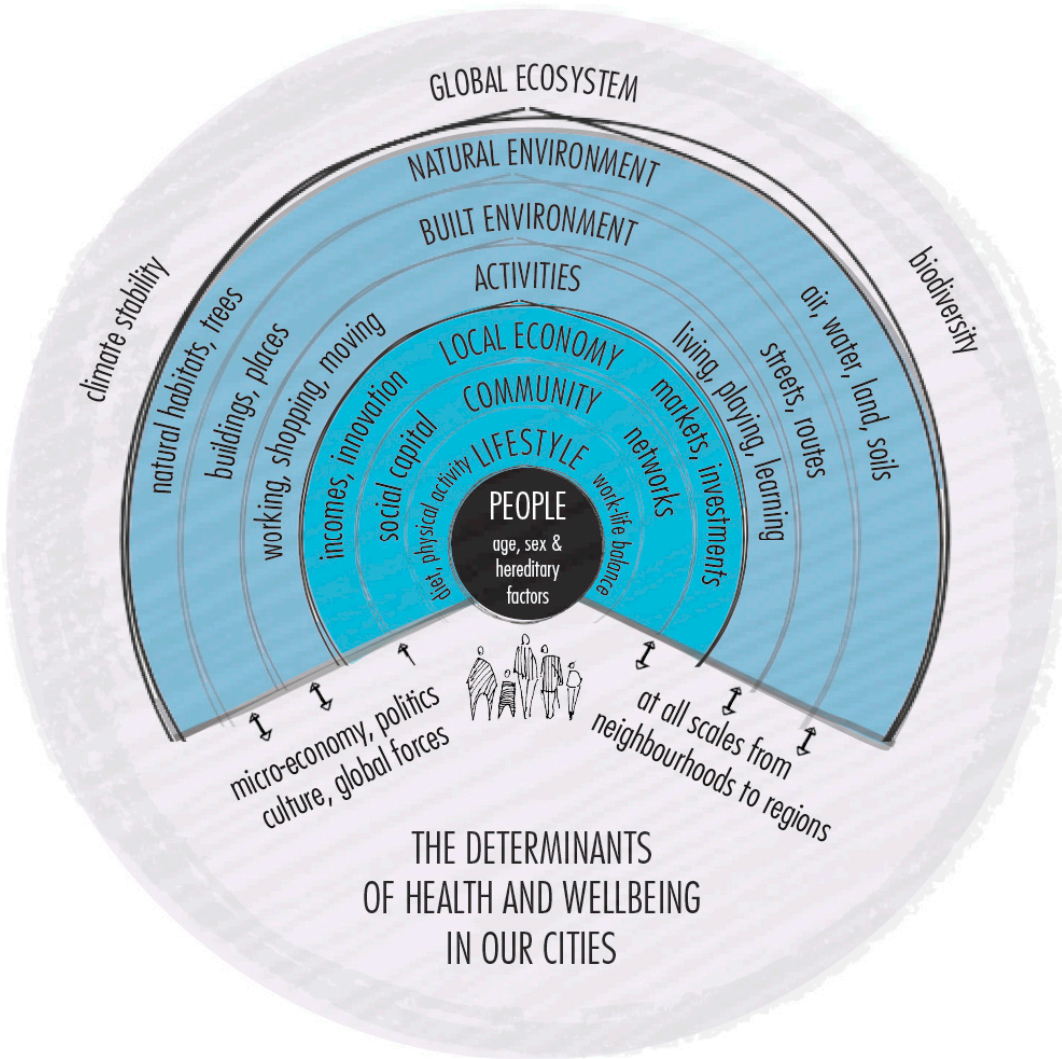

Figure 2. Health Map (Source: Barton and Grant 2006).

This diagram gives a greater focus to the environmental conditions that determine health. The built environment is structured in the model as one of several concentric arcs below the "global ecosystem" and "natural environment". They proposed that their model's strength is that "it can be used to analyse knock-on (indirect) effects, which are often much more significant in terms of health" (p. 3). Acknowledging the anthropogenic nature of prevailing definitions of sustainable development (following Brundtland 1987 [60]), Barton and Grant placed humans at the centre of their health map. It includes the biophysical environment as a determinant which is separated from the social determinants that influence health. Their model, however, does not address the reciprocal relationship between the biophysical environment and social determinants. For example, lifestyle decisions (such as riding a bike to work) will affect the health of the biophysical world. In turn, the biophysical world will affect human health in terms of lifestyle, living and working conditions. Any model developed for depicting UNS thus needs to recognize that, while there may be health, social, environmental, and social outcomes from urban design at the neighbourhood scale, these outcomes are not separated entities, but rather have feedback loops to and from other spatial scales.

\subsection{Why "Unhealthy Neighbourhood Syndrome"?}

UNS seeks to identify threats to human physical health and mental wellbeing at the neighbourhood scale. Superficially, it sounds like a larger scale version of sick building syndrome (SBS) [15,61], which is concerned with symptoms that people experience inside buildings. The term "sick building syndrome" (SBS) was endorsed by the World Health Organization in 1983 [62] to describe "a collection of nonspecific symptoms including eye, nose and throat irritation, mental fatigue, headaches, nausea, dizziness and skin irritations, which seem to be linked with occupancy of certain workplaces". In formal medical usage, 
"a syndrome is a set of medical signs and symptoms which are correlated with each other and often associated with a particular disease or disorder" [63]. By extension, it seems reasonable to extend this label to the extremely wide and diverse set of symptoms ascribed to unhealthy neighbourhoods too. However, UNS differs from SBS at two critical pointsits spatial scale and its complexity. For example, individual buildings can be more isolated from social, economic, and environmental outcomes than can the neighbourhoods in which they are located. As Ghaffarianhoseini et al. [15] argued, "the main problem is larger than the buildings-related challenges" since there are "broader environmental conditions [that] should be initially fixed up before being capable of entirely solving the building problems" (p. 113). Collectively, they suggest that it is not only the home, which is an important contributor to health and wellbeing, but its surrounding neighbourhood too. This comment suggests that tacking conditions at the neighbourhood level may itself have a trickle-down effect on building conditions. Moreover, while the focus of sick building syndrome is on features of buildings that contribute to poor physical health and wellbeing, the social nature of the neighbourhood means that poor physical health and wellbeing does not originate from physical elements of urban design decisions alone. For example, carcentric urban design encourages behavioural choices such as increased vehicle usage that in turn decreases air quality and undermines outdoor activity, so affecting human health. Urban design, that fails to provide alternative behavioural choices for mobility, encourages residents and visitors to threaten the health of fellow occupants of a neighbourhood. In this way, it is not only the physical urban design features that threaten human health and wellbeing, but also the decisions, arising from urban design, of people living and visiting the neighbourhood. Additionally, threats to human health and wellbeing at a neighbourhood level can be non-static (cars being a prominent example), while threats to humans at a building scale are more locationally constrained (e.g., mould). A syndrome in this paper is attached to unhealthy neighbourhood to characterise a set of medical signs and symptoms which are correlated with each other and often associated with a particular disease or disorder [64] (p. 177). Such considerations make UNS a significantly more complex topic to not just to unpack as an idea, but to act upon in practice.

Yet, despite these concerns about the term, a framework for diagnosing UNS could be a useful tool for built environment practitioners, health professionals and citizen advocacy groups. Its deployment could better enable them by enhancing understanding of neighbourhood health and wellbeing through identifying specific symptoms and recommending strategies for their mitigation. Use of this term could also help by redirecting attentionaway from the residents of neighbourhoods (that are showing disorder, disadvantage, or decline) as being, for instance, feckless or workshy [65]. Such a framework could refocus attention instead on the limiting nature of where people live as directly contributing to the damaging circumstances of their impoverished existence. Seen from this perspective, the disadvantaged can be considered not just as economically and socially exploited, but as spatially oppressed as well, confined to live in impoverished and impoverishing environments. Accordingly, this paper cautiously promotes the term UNS, not as a means of labelling specific neighbourhoods as being worthy of scrutiny, but rather as offering a framework for giving more explicit attention to how urban design may be able to contribute to the alleviation (or reinforcement) of the conditions leading to neighbourhood health and wellbeing.

\subsection{Contributors to and Effects of UNS}

The conceptual frameworks shown above are not exhaustive. Nevertheless, they suggest a shared conceptualization of what gives rise to healthy or unhealthy neighbourhoods. This acknowledges the interconnectedness of human health and wellbeing to social, economic, and environmental outcomes, as resulting from the interplay between the tangible and intangible, of physical and social, objective, and perceived factors. Moreover, through their repetitions, such diagrams suggest that their authors collectively posit that healthy built environments and sustainable ones have many similarities. The aspects of 
urban design that contribute negatively to UNS also affect the environment, exacerbating the effects of climate change. These detrimental features, in turn, affect human systems and infrastructure that again, in turn, affect individuals' physical and mental health-and so ultimately affect the health of whole neighbourhoods. Therefore, common features are characterised as being involved in mental health, physical health, and neighbourhood health. Their inter-relationships are complex and need to be further unpacked to draw out the tangle of connections between urban design decisions and the economic, social, and environmental consequences that flow from them, either directly or indirectly modifying human health and mental wellbeing. Unfortunately, much that has been written about health and urban design predates the publication of Figure 3 and its fourfold categorisations. Unsurprisingly, the contents of the pre-existing literature do not fit easily within these categories. What follows is our retrospective attempt to align what the literature contains with the categories, where possible. Table 2 lists key neighbourhood characteristics that are frequently reported in both academic and grey literature. The list indicates that a wide range of characteristics are used as signs of the presence or absence of healthy neighbourhoods.
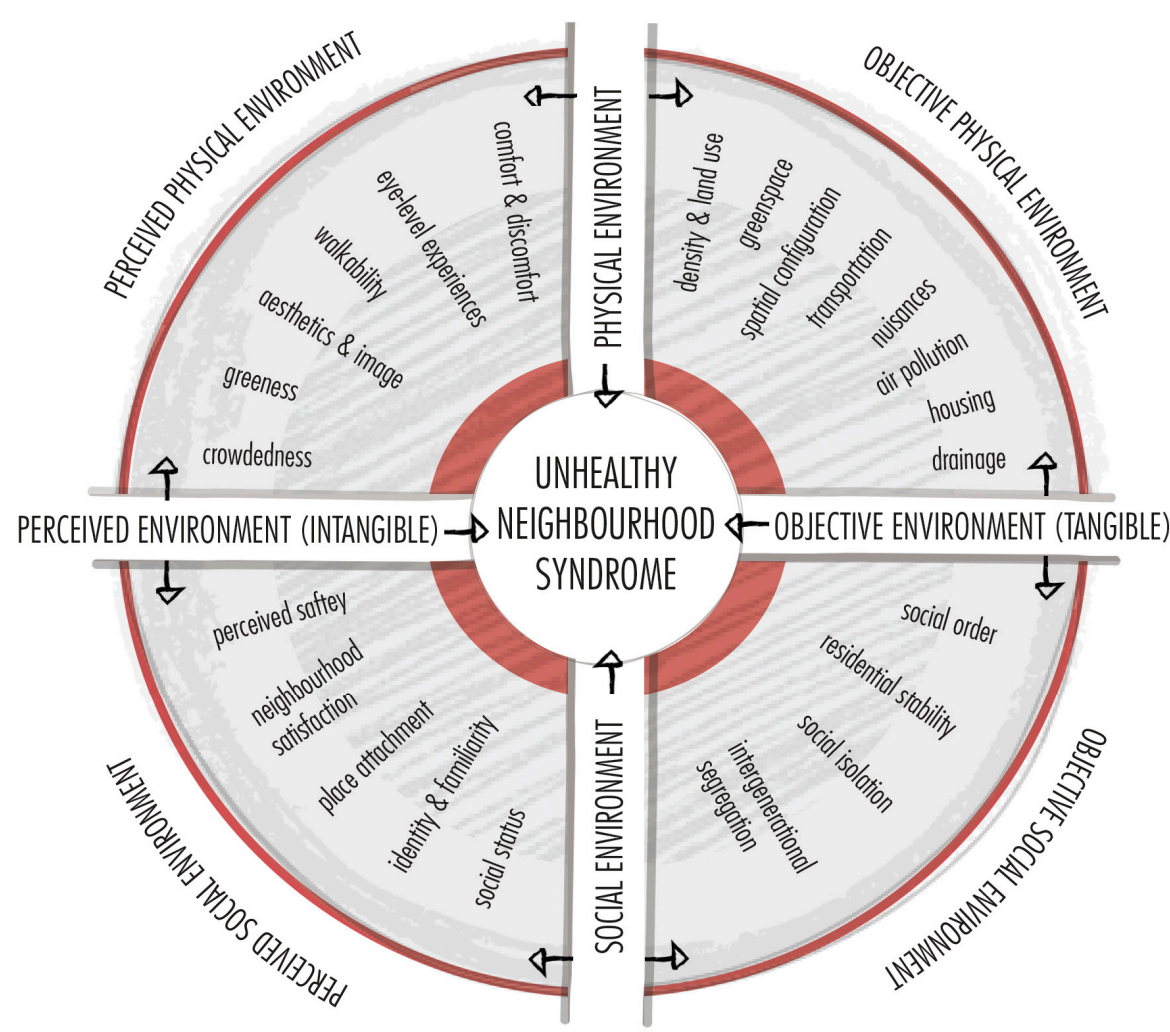

Figure 3. Conceptual Framework for understanding what contributes to Unhealthy Neighbourhood Syndrome (Adapted from Hajrasouliha et al. 2018).

In the literature reviewed, specific aspects of the physical environment are repeatedly identified as affecting the health of neighbourhoods. However, contradictory claims are often made about the outcomes of such effects. Similarly, perceptions of the physical environment are also repeatedly reported as contributing to poor physical health and mental wellbeing, whether acting directly or indirectly. The directions of these discerned effects are less contradictory than those reported for the physical components listed below.

Furthermore, the characteristics of the social environment are also identified as contributing to poor physical health and mental wellbeing, directly and indirectly [40]. People with good social connectivity sleep better at night, are more able to tackle adversity, live longer and consistently report feeling happier [66]. A wide range of other factors are also presented in the literature as being significant. In addition, people's perceptions 
of their social environment can also contribute to their poor physical health and mental wellbeing, both directly and indirectly. As Table 2 indicates, a range of factors have been associated with such effects.

Table 2. Reported effects and outcomes of physical and social environment factors.

\begin{tabular}{|c|c|c|c|}
\hline \multicolumn{4}{|c|}{ UNS: Physical Environment Factors } \\
\hline Physical Environment Factors & Effects & Outcomes & Identified Symptoms Associated with UNS \\
\hline Low density & $\begin{array}{l}\text { Low density can encourage less physical } \\
\text { activity and walking. }\end{array}$ & $\begin{array}{l}\text { Obesity, prevalence of hypertension, } \\
\text { and mortality }\end{array}$ & $\begin{array}{l}\text { Beenackers et al. [67] found that higher population density was modestly related to } \\
\text { higher mortality. Cooper and Boyko [68] also suggested that high density can result } \\
\text { in depression, strain, withdrawal, cognitive development, and reduced friendliness. }\end{array}$ \\
\hline \multirow[t]{2}{*}{ Land use patterns } & $\begin{array}{l}\text { Decisions about land use decisions can result in } \\
\text { an increase in car use and a decrease in } \\
\text { active transportation. }\end{array}$ & $\begin{array}{l}\text { Cardiovascular disease, stroke and } \\
\text { all-cause mortality }\end{array}$ & $\begin{array}{l}\text { The management of land is also held to contribute to poor mental and physical } \\
\text { health by affecting the location of goods and services. For example, Barton [69] } \\
\text { reported that supermarket proximity can influence the availability of healthy food } \\
\text { options, the absence of which can lead to poor diet and obesity. Land use patterns } \\
\text { can also encourage car use if, for example, employment locations are isolated } \\
\text { without sufficient public transportation options. } \\
\text { Frank et al. [70] (p. 1) identified "land-use mix" as having "a strong association } \\
\text { with obesity (BMI30 } \mathrm{kg} / \mathrm{m}^{2} \text { ), with each quartile increase being associated with a } \\
12.2 \% \text { reduction in the likelihood of obesity across gender and ethnicity". }\end{array}$ \\
\hline & $\begin{array}{l}\text { They can also aggravate access to healthy } \\
\text { food options. }\end{array}$ & Poor diet and obesity & \\
\hline Vacant and Derelict Land (VDL) & $\begin{array}{l}\text { VDL can negatively affect community } \\
\text { wellbeing, and community perceptions of the } \\
\text { local area. } \\
\text { VDL may inhibit or prohibit movement } \\
\text { through an area restricting social interaction } \\
\text { influencing feelings of personal safety. }\end{array}$ & $\begin{array}{l}\text { Increased anxiety levels, agitation } \\
\text { and anger } \\
\text { Increased incidence of crime and } \\
\text { antisocial behaviours }\end{array}$ & $\begin{array}{l}\text { The Scottish Land Commission [71] reported a spatial association between } \\
\text { interaction with VDL and physical health, recording poorer health outcomes, } \\
\text { population health and life expectancy. VDL may also inhibit or prohibit movement } \\
\text { through an area by influencing feelings of personal safety and by restricting } \\
\text { interaction/use due to fencing and hoardings. As well as these direct affects, } \\
\text { VDL was reported to have significant effects on a community's perceptions of its } \\
\text { local area. }\end{array}$ \\
\hline Greenness and connect with nature & $\begin{array}{l}\text { A lack of accessible greenspace can lead to less } \\
\text { social interaction and physical activity. }\end{array}$ & $\begin{array}{l}\text { Lower mental wellbeing, increased } \\
\text { stress, inactivity and less social activity }\end{array}$ & $\begin{array}{l}\text { Urban greenspace [72] is also reported to have a negative effect on health by } \\
\text { exposing people to "allergenic pollen, infections transmitted by arthropod vectors } \\
\text { such as ticks or mosquitoes, and risk of injuries". Additionally, a systematic review } \\
\text { by Jones and Yates for the Glasgow Centre for Population Health [73] (p. 15) found } \\
\text { decreased access to greenspace is associated with "lower mental wellbeing, } \\
\text { increased stress, inactivity and less social activity". }\end{array}$ \\
\hline Spatial Configuration & $\begin{array}{l}\text { Urban sprawl can lead to greater car use and } \\
\text { less use of active transportation options. }\end{array}$ & $\begin{array}{l}\text { Undermined social ties leading to lower } \\
\text { mental health } \\
\text { Obesity and prevalence of hypertension }\end{array}$ & $\begin{array}{l}\text { The spatial configuration of a neighbourhood is also reported to contribute to poor } \\
\text { physical health and mental wellbeing. As neighbourhood is a physical and social } \\
\text { construction, according to Barton [10] (p. 101) "each person conceives their own } \\
\text { neighbourhood, depending on where they live, what connections they have locally" } \\
\text { and that "it is vital that spatial patterns do not frustrate these very varied } \\
\text { individual connections, but facilitate them". Sim [38] (p. (359) described space with } \\
\text { no or little spatial clarity or sense of containment as lacking a sense of identity and } \\
\text { shared ownership; wide open spaces that do not encourage social interaction and } \\
\text { repel human activity prevent a sense of ownership from emerging (ibid.). } \\
\text { Frumkin [74] presented sprawl (i.e., unrestricted urban development over a wide } \\
\text { area of land) as contributing to negative health consequences through loss of social } \\
\text { capital, social stratification, higher air pollution and health stress, physical } \\
\text { inactivity and obesity. Ewing et al. [75] portrayed sprawl as reducing minutes } \\
\text { walked so leading to higher obesity and prevalence of hypertension. Freeman [76] } \\
\text { depicted sprawl and vehicle-based urbanism as undermining social ties among } \\
\text { neighbourhoods, as discouraging residents from interacting with their neighbours. }\end{array}$ \\
\hline Transportation & $\begin{array}{l}\text { Prioritizing private car travel can contribute to } \\
\text { longer commuting times, fatigue and } \\
\text { chronic stress. }\end{array}$ & $\begin{array}{l}\text { Cardiovascular abnormalities and } \\
\text { dysfunction related to the onset of } \\
\text { heart disease } \\
\text { Increased blood pressure and anxiety }\end{array}$ & $\begin{array}{l}\text { Car use can also affect pedestrian safety, with motor vehicle-related injuries } \\
\text { continuing to disproportionately affect those without access to a vehicle, such as } \\
\text { poor, young and older adults [77,78]. Gatersleben and Uzzell [79] characterised } \\
\text { passive modes of transportation, such as by car or public transportation, as being } \\
\text { more stressful and boring. Lyons and Chatterjee [80] reported that the effects of } \\
\text { long commutes, such as fatigue and chronic stress, can induce cardiovascular } \\
\text { abnormalities and dysfunction related to the onset of heart disease. Moreover, } \\
\text { Frank et al. [70] (p. 1) identified "each additional hour spent in a car per day was } \\
\text { associated with a } 6 \% \text { increase in the likelihood of obesity. Longer commuting times } \\
\text { reportedly; makes people more tired" [81]; can result in reduced sleep time [82]; } \\
\text { can increase blood pressure [83] and anxiety [84]; and can negatively affect life } \\
\text { satisfaction, stress, and family life [84,85]. }\end{array}$ \\
\hline Noise & Nuisances can lead to sleep deprivation. & $\begin{array}{l}\text { Various mental health and physical } \\
\text { health symptoms }\end{array}$ & $\begin{array}{l}\text { The UK's Royal Commission on Environmental population reported [86] that } \\
\text { excessive and persistent noise may lead to poor mental health due to sleep } \\
\text { disturbances and annoyance. Additionally, the Scottish Government [ } 87 \text { ] stated } \\
\text { that noise-related problems can be more prevalent in areas of socioeconomic } \\
\text { disadvantage. Likewise, a nationwide Danish study [88], among individuals living } \\
\text { in multi-story housing, identified neighbourhood noise annoyance as being } \\
\text { associated with various mental and physical health symptoms. }\end{array}$ \\
\hline Air pollution & $\begin{array}{l}\text { Air pollution can result in exposure to NOx } \\
\text { and } \mathrm{SO} 2 \text { pollutants. }\end{array}$ & $\begin{array}{l}\text { Exposure associated with diabetes and } \\
\text { neurological diseases connected to lower } \\
\text { levels of happiness and poor } \\
\text { mental health. } \\
\text { Air pollutants have also been associated } \\
\text { with incidence of Parkinson's disease } \\
\text { and non-Alzheimer's dementia. }\end{array}$ & $\begin{array}{l}\text { The UK Green Building Council [89] identified that air pollution is associated with } \\
\text { diabetes and neurological diseases and can affect time of pregnancy and birth } \\
\text { weight. The UK's Department for Environment, Food and Rural Affairs [90] linked } \\
\text { air pollution not only to cancer, but also to stroke and heart disease, diabetes, } \\
\text { obesity, and changes linked to dementia. It added that the health effects of air } \\
\text { pollution disproportionately affect older adults, children, and these with existing } \\
\text { respiratory conditions (ibid.). Moreover, air pollutants have also been associated } \\
\text { with incidence of Parkinson's disease and non-Alzheimer's dementia [91]. } \\
\text { Sustrans [92], the UK walking and cycling charity, concluded that air pollution can } \\
\text { contribute to greater health inequalities in deprived communities, because they are } \\
\text { more likely to be located near busy roads rather than secluded streets. Air pollution } \\
\text { both real and perceived have also been reported [93,94] to affect mental health and } \\
\text { as being connected to lower levels of happiness. }\end{array}$ \\
\hline Housing & $\begin{array}{l}\text { Many housing factors can affect mental and } \\
\text { physical health, such as, but not limited to, } \\
\text { dampness, noise, lighting, air quality, tenure } \\
\text { and design. }\end{array}$ & $\begin{array}{l}\text { Association between large building } \\
\text { types and negative social relations } \\
\text { leading to decreased social cohesion, } \\
\text { neighbourliness and social capital } \\
\text { compared to single-unit housing. }\end{array}$ & $\begin{array}{l}\text { Many aspects of housing were reported by Macdonald and Thompson [95], } \\
\text { as affecting both mental and physical health, such as dampness, noise, lighting, } \\
\text { air quality, tenure, and design. King [96] found an association between large } \\
\text { building types and negative social relations, (including social cohesion, } \\
\text { social capital, and neighbourliness) in contrast to single-unit housing. } \\
\text { Other studies [97-99] suggested several symptoms for sick building syndromes, } \\
\text { affecting different parts of the human body, ranging from headache, fatigue, } \\
\text { and irritation in upper respiratory tract to nose, throat, eyes, and dermal } \\
\text { abnormalities. Ghaffarianhoseini et al. [15] categorised these symptoms into eight } \\
\text { main groups: respiratory, nasal, ocular, oropharyngeal, cutaneous, lethargy, } \\
\text { cognitive and general. }\end{array}$ \\
\hline Insufficient drainage and buffer capacity & $\begin{array}{l}\text { The accumulation of local rainfall runoff due to } \\
\text { insufficient drainage and buffer capacity } \\
\text { leading to flooding. }\end{array}$ & $\begin{array}{l}\text { Threats to physical health (mortality) } \\
\text { and poor mental health. Survivors can } \\
\text { suffer psychosocial effects such as } \\
\text { distress, anxiety, pain and depression }\end{array}$ & $\begin{array}{l}\text { Alderman et al. [100] catalogued how the accumulation of local rainfall runoff due } \\
\text { to insufficieint drainage and buffer capacity can result in flooding threatening } \\
\text { physical health (mortality) and contributing to poor mental health due to flooding } \\
\text { threats. Foudi et al. [101] found that survivors can suffer psycho-social effects such } \\
\text { as distress, anxiety, pain, depression, and social dysfunctions. }\end{array}$ \\
\hline
\end{tabular}


Table 2. Cont.

\begin{tabular}{ccc}
\hline & \multicolumn{1}{c}{ UNS: Perceived Physical Environment Factors } \\
\hline Perceived Physical Environment Factors & \multicolumn{1}{c}{ Outcomes } \\
\hline Crowdedness & Can lead to feeling that people are too close & Correlated negatively with quality of life \\
\hline Accessibility & $\begin{array}{l}\text { A perception that destinations are not } \\
\text { accessible (e.g., by walking, cycling or by } \\
\text { mobility assisted devices) }\end{array}$ & Effect on subjective wellbeing \\
\hline Greenness & $\begin{array}{l}\text { A lack of perceived access to greenspace or } \\
\text { trees can lead to avoidance of public realm, } \\
\text { decreased social interaction and } \\
\text { physical activity. }\end{array}$ & Effect on subjective wellbeing \\
\hline
\end{tabular}

Aesthetics, and Physical appearance

A perceived lack of aesthetic beauty (e.g. tall building heights, poorly maintained streets parks and buildings). Negative effect on restorative potential
More likely to experience lower levels of mental wellbeing.
Crowding cannot be defined objectively [102], but rather is a perceived state of mind and the feeling of other people being too close. Crowdedness needs to be distinguished from density, as it has no inherent positive or negative connotations,
but the former does. Gray [102] defined over-crowdedness as a perceived level of density that has a detrimental effect on psychological and mental wellbeing. McCrea, Shyy and Stimson [103] agreed that perceived crowdedness correlated negatively with quality of life.

McCrea, Shyy and Stimson [103] found that perceived accessibility to goods and services influenced subjective wellbeing, while actual proximity was shown to have perceived accessibility (or lack of this) has beent, over time,

Bjornstrom and Ralston [105] stated that a high prevalence of trees in a neighbourhood can lead to it being perceived as dangerous, resulting in a decrease in social cohesion.

Lindal and Harti [106] stated that building heights had a negative effect on restorative potential, defined by Scopelliti, Carrus and Bonaiuto [107] as "the capacity for natural environments to replenish cognitive resources depleted by everyday activities and to reduce stress levels" (p. 1). Moreover, people who perceive their neighbourhoods to be dirty and poorly maintained have been identified as more likely to experience lower levels of mental wellbeing $[108,109]$ Such perceptions are disproportionately felt by older adults, women and the mployed $[50,110]$

Jun and Hur [111] suggested that, even in areas where physical walkability (proximity) is high, residents may walk less if they perceive their neighbourhood a unsafe for walking in. Therefore, they advised that future places should examine the unique relationship between the proximity and functions of public facilities with their urban contexts-the proximity of other community services to residences, neighbourhoods would help in initiating the healthy lifestyles of citizens.

Karssenberg et al. [112] claimed although "the ground floor may be only $10 \%$ of a building but it determines $90 \%$ of the building's contribution to [a person's] experience of the environment" (p. 16). How a building meets the street, they maintained, can promote social isolation, limiting opportunities for social interaction. Ground floors that are "inactive" (without windows looking onto the street, no patio furniture, plants, artwork, etc.) can promote feelings of insecurity through more coming and goings (ibid.). Sim [38] (p. 83) described inactive ground interesting, and so less enjoyable to the senses.

Perceiving a built environment as uncomfortable is held to lead to several undesirable behavioural decisions that can contribute to poor physical and mental health. Sim [38] (p. 272) explained that "human beings are highly sensitive to unpleasant physical and climatic phenomena. When there is an interruption or disconnect between one place and another because of a bad experience, patterns of behaviour are lost, and people are much less likely to walk or spend time in that place)." Discomfort and nuisances can manifest themselves in a variety of ways

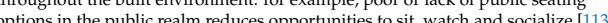
options in the public realm reduces opportunities to sit, watch and socialize [11.3. macro social interactions are provided, social isolation and loneliness rises as people avoid the public realm. Zhang [115] held that element of the built environment that are perceived as uncomfortable depress use of alternatives to private vehicle. Uncomfortable or lack of seating at public transportation stops can decrease waiting, so depressing passenger levels.

\begin{tabular}{|c|c|c|c|}
\hline \multicolumn{4}{|c|}{ UNS: Social Environment Factors } \\
\hline Social Environment Factors & Effects & Outcomes & Identified Symptoms Associated with UNS \\
\hline Social Order and Social Cohesion & $\begin{array}{l}\text { Low social order and social cohesion can lead } \\
\text { to neighbourhood instability. } \\
\text { Can increase levels of psychological } \\
\text { distress stress. }\end{array}$ & Psychosis and depression & $\begin{array}{l}\text { A lack of social cohesion in urban areas has been identified as contributing to } \\
\text { psychosis and depression [116-118]. }\end{array}$ \\
\hline Residential Stability & $\begin{array}{l}\text { Residential instability can lead to } \\
\text { chronic homelessness. } \\
\text { Can increase levels of psychological } \\
\text { distress stress. }\end{array}$ & $\begin{array}{l}\text { Mortality and poor physical and } \\
\text { mental health }\end{array}$ & $\begin{array}{l}\text { People who are chronically homeless and do not have residential stability have } \\
\text { higher morbidity, such as increased mortality and poor physical and mental health } \\
\text { [119,120]. Persons who are not homeless, yet still face home instability, are more } \\
\text { likely to experience poor health compared to people who have residential } \\
\text { stability [121]. }\end{array}$ \\
\hline Reduced social capital and social isolation & $\begin{array}{l}\text { Low socio-economic status can lead to poor } \\
\text { self-esteem, feelings of inferiority, frustration } \\
\text { and hopelessness. } \\
\text { Can increase levels of psychological } \\
\text { distress stress. }\end{array}$ & Poor mental health & $\begin{array}{l}\text { Gehl [122] argued that a low priority has been given to public space as a meeting } \\
\text { place, because of the ideologies, such as modernism, that dominated planning and } \\
\text { urban designer throughout the last half of the twentieth century. He held (p. 3) that } \\
\text { the design of modern cities prioritizes communication and transportation } \\
\text { infrastructure for industry over other considerations, contributing to inequality } \\
\text { within urban environment, since "the traditional function of city space as a meeting } \\
\text { place and social forum for city dwellers [was] reduced, threatened or phased out". } \\
\text { This is not a new observation. Ward [123] (p. 25) had already concluded, } \\
\text { three decades previously, that cities had been built "deliberately for one particular } \\
\text { kind of citizen: adult, male, white collar, out of town car-user". Zeiher [124] (p. 66) } \\
\text { noted that cities designed with an emphasis on vehicular traffic intensify a process } \\
\text { of " "insurlarisation", creating a growing separation between places built to meet } \\
\text { people's needs. Christensen and O'Brien [125] (p. 7) agreed, suggesting that, } \\
\text { for some adults, if walking between their "islands of activity, is too dangerous or } \\
\text { too far to commute, then driving is the preferred option". However, driving is a } \\
\text { luxury available only to those who can afford and choose to drive. This rationing } \\
\text { by price has led to an increase in social isolation and reduced social capital between } \\
\text { neighbourhood residents. This has, in turn, led to reductions in social capital which, } \\
\text { they reported, can be disproportionately felt by older adults and young children, } \\
\text { especially within age-segregated neighbourhoods. }\end{array}$ \\
\hline
\end{tabular}


Table 2. Cont.

\begin{tabular}{|c|c|c|c|}
\hline Intergenerational segregation & $\begin{array}{l}\text { Urban life has become increasingly isolated } \\
\text { and segregated. }\end{array}$ & $\begin{array}{l}\text { Increase anxiety. } \\
\text { Poor mental health and physical health } \\
\text { increase levels of psychological } \\
\text { distress stress. }\end{array}$ & $\begin{array}{l}\text { Manchester and Facer [126] identified that over the last two decades, interaction } \\
\text { between generations in public spaces has diminished: positive contact have } \\
\text { reduced as children and older adults alike are encouraged to live and spend time in } \\
\text { age-segregated spaces where physical barriers such as gates and high walls } \\
\text { predominate. They reported that fear and competition over resources and policies } \\
\text { have also contributed to our cities becoming increasingly segregated on } \\
\text { generational lines (p. 5). Vanderbeck and Worth [127] (p. 4) argued that } \\
\text { intergenerational segregation results from patterns of design that "have } \\
\text { contributed to the production of spaces-such as city centres-that can prove } \\
\text { relatively inaccessible or unwelcoming to people of particular life stages". } \\
\text { van Vliet [128] (p. 349) described how, since young children and older adults are } \\
\text { not workers in most Western market-based economies, their needs are often } \\
\text { overlooked. Without being part of the workforce, both groups "cannot translate } \\
\text { their needs into a market demand". Wu and Chan [129] (p. 2) agreed, noting that } \\
\text { accordingly, older adults "tend to travel outside their own neighbourhoods less } \\
\text { often than do younger aulults". As both older adults and children can experience } \\
\text { restricted mobility, participating in social interactions can become difficult for them } \\
\text { [130,131]. They reported that, by overlooking the needs of older adults and young } \\
\text { children in particular, urban life has become increasingly isolated and segregated. }\end{array}$ \\
\hline \multicolumn{4}{|c|}{ UNS: Perceived Social Environment Factors } \\
\hline Perceived Social Environment Factors & Effects & Outcomes & Identified Symptoms Associated with UNS \\
\hline Perceived Safety & $\begin{array}{l}\text { A perceived threat to safety can lead to lower } \\
\text { levels of physical activity and dissuade certain } \\
\text { groups (e.g., women) from physical exercise } \\
\text { and can increase levels of psychological } \\
\text { distress stress. }\end{array}$ & Poor mental health and physical health & $\begin{array}{l}\text { A growing body of literature reporting public health research suggests that } \\
\text { perceived neighbourhood safety is linked to health outcomes [132-134]. } \\
\text { For example, Hale [135] linked perceived threats to safety to lower levels of } \\
\text { physical activity. Bjornstrom and Ralston [105] (p. 45) demonstrated that } \\
\text { "perceived danger and concentrated disadvantage have strong negative } \\
\text { correlations with perceived cohesion, regardless of the built environment objective } \\
\text { characteristics". Negative perceptions of a neighbourhood's safety have been } \\
\text { associated with anxiety, poor health outcomes [136] and poor self-rated health [133]. } \\
\text { Additionally, feeling unsafe within a neighbourhood can contribute to people } \\
\text { (particularly women in low-income neighbourhoods) not using the built and } \\
\text { natural environment for exercise [137,138]. }\end{array}$ \\
\hline Neighbourhood Satisfaction & $\begin{array}{l}\text { A lack of neighbourhood satisfaction; residents } \\
\text { in their neighbourhood can have an effect on } \\
\text { physical activity within the neighbourhood } \\
\text { and can increase levels of psychological } \\
\text { distress stress. }\end{array}$ & $\begin{array}{l}\text { Lower physical activity and } \\
\text { self-rated health }\end{array}$ & $\begin{array}{l}\text { Stronegger et al. [139] reported that neighbourhood satisfaction can have an effect } \\
\text { on physical activity and self-rated health. Stokols and Shumaker [140] attested that, } \\
\text { without an attachment to place, people experience higher stress levels and more } \\
\text { health problems. }\end{array}$ \\
\hline $\begin{array}{l}\text { Place Attachment (sense of place), Identity } \\
\text { and familiarity }\end{array}$ & $\begin{array}{l}\text { An absence of place attachment can increase } \\
\text { levels of psychological distress stress. } \\
\text { A lack of control to influence local environment } \\
\text { can increase levels of psychological } \\
\text { distress stress. }\end{array}$ & Poor mental health & $\begin{array}{l}\text { Stokols and Shumaker [140] attested that, without an attachment to place, } \\
\text { people experience higher stress levels and more health problems. } \\
\text { Karssenberg et al. [112] noted that a lack of neighbourhood activities such as local } \\
\text { markets and events can also contribute to a perceived diminished local identity. } \\
\text { Similarly, they suggested that neighbourhoods with places with blank or } \\
\text { uninteresting facades can contribute to a perceived lack of neighbourhood identity. }\end{array}$ \\
\hline Social Status & $\begin{array}{l}\text { A person's perceived low standing or } \\
\text { importance in relation to other people within a } \\
\text { society can increase levels of psychological } \\
\text { distress stress. }\end{array}$ & $\begin{array}{l}\text { Depression. } \\
\text { Cardiovascular disease and } \\
\text { immune function }\end{array}$ & $\begin{array}{l}\text { A person's perception that they have low social status (relative to the perceived } \\
\text { standing or importance in relation of other people within a social group) can have a } \\
\text { range of associated effects: depression [141], cardiovascular disease [142], } \\
\text { and immune malfunction [143]. }\end{array}$ \\
\hline
\end{tabular}

The sheer length of this list of physical and perceived neighbourhood factors, and their claimed effects and outcomes, creates an impression that, taken together, they encompass almost everything. This, understandably, leads not just to a loss of conceptual specificity and diagnostic clarity, but to misgivings about how the situations so described can possibly be tackled in practice. It is possible to derive a framework to show the elements that urban designers have been advised can contribute to poor physical health and mental wellbeing in neighbourhoods. The mechanisms through which these contributions are held to occur are manifold: physical and social environment and perceived and objective environment, as shown in Figure 3.

This framework is useful because it recognizes that the built environment is composed of interconnected physical and social elements which are mediated by how these are perceived. Perceptions of built and social environments influence how neighbourhoods are experienced: this, in turn affect physical and mental health Hajrasouliha et al.'s [144]. As Sim [38] suggested, a neighbourhood is thus more than just its physical parts: it also gives rise to feelings, and so can produce a state of mind in those who experience it. However, this framework conceals as well as reveals, because it ignores the power dynamic which underlies and differentiates between the lived experience of groups of people who live in neighbourhoods.

\section{Part Two: Manipulating Urban Design to Affect Physical Health and Mental Wellbeing at the Neighbourhood Scale}

As aspects of the built environment are held to affect people's physical health and mental wellbeing, manipulation of these aspects by urban designers is seen as offering opportunities to improve their health and wellbeing. Accordingly, mitigating UNS means not only reducing and eliminating aspects of neighbourhood urban design that contribute to poor physical health and mental wellbeing, but also enhancing those that give people options for making choices that positively affect their health and wellbeing. Accordingly, 
any discussion of strategies to mitigate UNS has to recognize the potential of urban design decisions to affect people's lived experiences and their personal choices. There is, however, no agreement in the literature about how many issues need to be addressed, for example, Carmona [20] (pp. 12,13) suggested that the way in which places are designed can deliver beneficial health outcomes directly and indirectly (physical health and mental wellbeing), by tackling six issues:

- better physical health: lower obesity, less type 2 diabetes, lower blood pressure, reduced heart disease, lower rates of asthma and respiratory disease, faster recovery from illness, and from fatigue;

- $\quad$ better general fitness: increased walking (for both travel and recreation), increased exercise, sport and recreation, and more cycling;

- greater daily comfort: reduced air pollution, heat stress, traffic noise and poor sanitation, and reduced exposure of lower socio-economic groups to the effects of debilitating neighbourhoods;

- $\quad$ enhanced quality of life in terms of increased sense of emotional wellbeing and satisfaction, greater happiness, reduced fear and higher energy levels;

- $\quad$ better mental health: less stress and more psychological restfulness, reduced depression, anxiety and anger, reduced psychosis).

Due to length constraints, it is beyond the scope of this paper to look into how urban design can be used to mitigate all factors reported in Table 2, so instead, we will focus on recurring themes affecting physical health and mental wellbeing at the neighbourhood scale.

Synthesizing advice on Physical Health: In the literature reviewed here, there are inconsistencies between what individual authors deem is most important and so, by extension, how many factors should be given attention in urban design. In what follows, these inconsistencies are acknowledged before attempts are made, in the figures provided, to indicate relationships between what are identified as key factors. According to Barton [10] four key areas of decision making for urban design, which have far-reaching effects on physical health in neighbourhoods, can be reported. These four focus on decisions about: urban density, greenspace, movement, and housing (see Figure 4). In Figure 4, we have linked these key decisions to what London [6] suggested are the eight relevant spatial planning and urban design criteria for mitigating UNS.

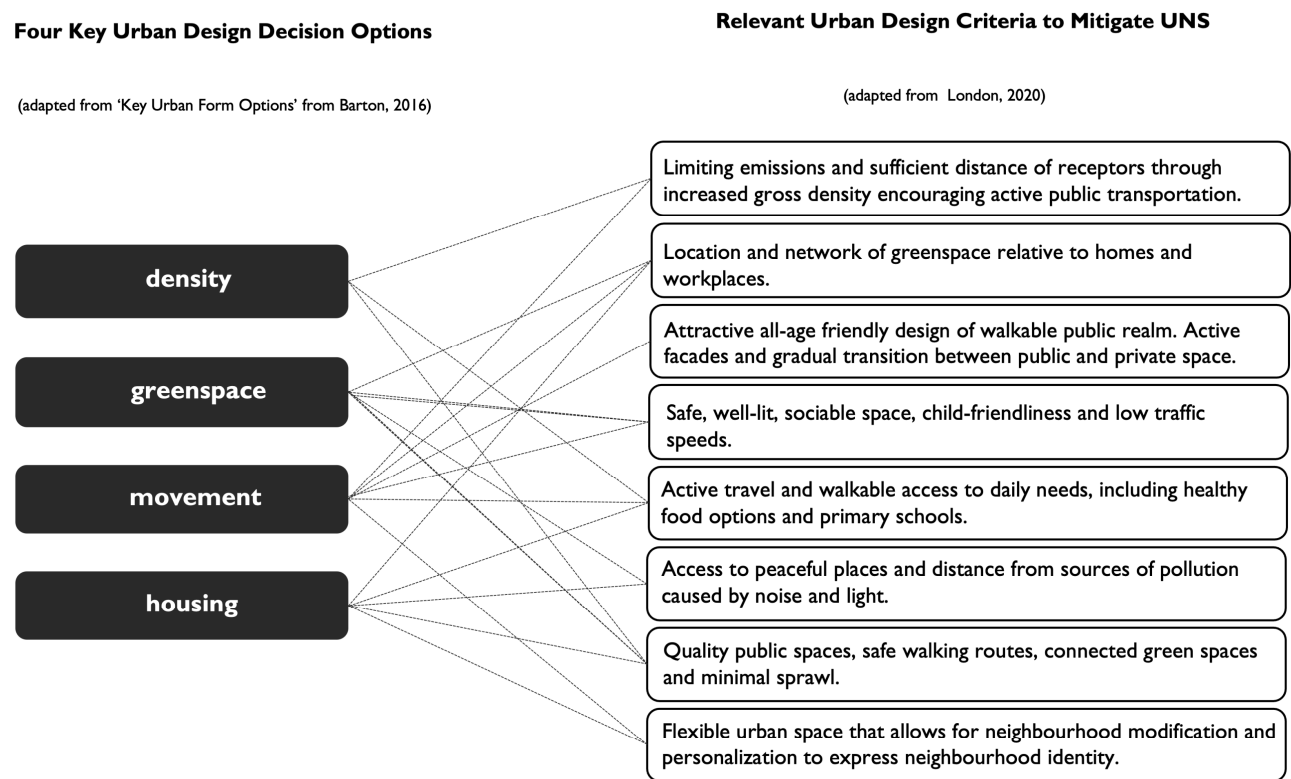

Figure 4. Linking Barton's four key areas in decision making about urban design to London's eight criteria for mitigating Unhealthy Neighbourhoods. 


\subsection{Decisions about Urban Density}

Attempting to manipulate density to mitigate UNS is complex and depends on context. According to Barton [10] (p. 199), in the UK, this requires a medium net residential density of 40-50 dpha (dwellings per hectare) (around 100 ppha), which implies mainly terraced development. These, he suggested, "have been widely advocated". Housing density must also be complemented by gross neighbourhood density if residents are to benefit from enhanced access to facilities, opportunities for active travel and frequency of social interaction, in order to mitigate SN. Barton [10] advocated a gradual easing of density provides choices for residents that suits their social needs. He suggested (p. 200) "the grading of densities for all users- high density close to high streets, lower further away and towards the main greenspace network-gives logic to location decisions. The point is to maximize accessibility and choice". Sim [38] (p. 63) argued that, in general, a diverse urban density also can mitigate feelings of social isolation and physical threats to safety, "a mixture of dwellings, workplaces, businesses, and services will ensure that there are people on a block at all hours. Different kinds of residents and users are at home and awake at different times of the day, which is particularly important for crime prevention". Talen and Koschinsky [145] advised that compact, walkable, diverse districts can lead to better general health, more social interaction and enhance safety. Similarly, an increase in land-use mix is presented as promoting walking and reducing obesity [70,146]. To reiterate, context is crucial, but in general, higher density combined with a mix of uses is viewed as helping contribute to mitigating many physical and mental health threats associated with unhealthy neighbourhoods.

\subsection{Decisions about Greenspace}

The RTPI [23] recommended that a multifunctional greenspace network can contribute to enhanced use of greenspace, accompanied by additional benefits arising from access to nature. Trees and plants themselves can reduce local air pollution with pollution sticking to leaves to later be washed away from rain, while other pollutants may be processed by plants. These ecological services remove atmospheric greenhouse gases (GHGs), mitigate local temperature, and mitigate flood risk (ibid.). Barton [10] suggests that the effect of greenspace can be enhanced through a connected network as "continuity is important, linking between varied features, for recreation routes, wildlife corridors and climatic/pollution management" (p. 181).

White et al. [147] reported that the increased provision of greenspace is also associated with higher levels of physical activity, which has been identified [148] to reduce the risk of colon and breast cancer and ischaemic heart disease. Ogen et al. [149] (p. 971) found that access to greenspace close to home affected the prevalence rate of disease. Ulmer et al. [150] identified urban tree cover as promoting lower obesity, better social cohesion, less type 2 diabetes, high blood pressure and asthma. The United Kingdom Green Building Council (UKGBC) [89] reported that a connection with nature has been found to lower blood pressure, glucose levels and the serotonin-melatonin balance that can affect mood and energy levels. Liu et al. [151] identified access to an urban park as enhancing mental health (self-confidence, energy levels, self-perceived health, mood restoration and relaxation.

Quite how and why access to nature can mitigate elements of poor mental health is a source of continued debate. What is clearer however, is the effect of such green elements. According to Wilson [152], biophilia theory suggests that human beings have an innate emotional affiliation to other living organisms. This emotional connection has been theorized as improving mental health and wellbeing. Kaplan and Kaplan [153] argued, via their Attention Restoration Theory, that spending time in nature restores our attentional capacity. Urlich [154] promoted stress reduction theory to suggest being in an unthreatening natural environment after stressful situations rapidly promote physiological recovery and relaxation. In a study of deprived communities, Ward Thompson et al. (p. 1) found that "results indicate significant relationships between self-reported stress $(p<0.01)$, diurnal patterns of cortisol secretion $(p<0.05)$, and the quantity of green space in the living 
environment". Roe and Aspinall [155] reported that, for children, access to green space had a positive effect on their mood, that included energy levels, stress, and anger.

There is even a claim that simply viewing greenspace can have positive health and wellbeing effects. Burton, Mitchell and Stride [156] found a green view from living spaces enhance general wellbeing. Velarde, Fry, and Tveit [157] reported that viewing green landscapes, as compared to urban ones, improve short-term recovery from stress or mental fatigue, faster physical recovery from illness, and enhance long-term overall health and wellbeing. Kaplan [158] found that the ability to view natural views from home (including gardens and flowers) increased neighbourhood satisfaction. Additionally, Lohr and Pearson-Mims [159] suggested that the positive effect of green environments arises, in part, because humans have an emotional response to trees (rounded not conical) that produce positive emotional responses making us happier, friendlier, more attentive, less angry, less sad and less fearful. Unsurprisingly then, Benzeval et al. [160] held that access to greenspace is particularly important for low-income households who face greater financial barriers to exercise facilities and gymnasiums and subsequently have poorer physical health and higher incidences of moderate or severe mental illness.

\subsection{Decisions about Movement}

Pinto et al. [17] reported that incentivising and encouraging active transportation options, such as walking, cycling and public transportation over private vehicles, can lead to various health and wellbeing benefits for residents and visitors to a neighbourhood. They advised that living in a well-planned neighbourhood with an active transportation network can encourage walking and cycling, enabling up to $59 \%$ of the 150 min of physical activity it recommended for adults by the UK's National Health Service (NHS) [161]. Sim [38] (p. 135) explained that encouraging public transport and active transportation options can mitigate social isolation through enhanced social interactions via "small movements around the neighbourhood, for crossing the street, getting our bike onto the bike lane, and waiting for the bus. All of these small movements, using different forms of mobility, are opportunities for sociability-invitations for people to connect with other people". Encouraging public transportation and active transportation options over private vehicles is promoted as mitigating a wide range of negative physical health outcomes. The NHS [161] advised that regular physical activity can reduce the risk of stroke, heart disease, type 2 diabetes by up to $50 \%$, and early death by up to $30 \%$. Frank et al. [70] (p. 1) identified that "each additional kilometre walked per day is associated with a $4.8 \%$ reduction in the likelihood of obesity". Sim [38] (p. 135) noted that "It is recommended to get at least 10,000 steps every day. Every daily trip offers the opportunity to walk more, stay more, do more outside, and spend more time with other people". Sinnett et al. [162] recommended that street improvements can make a difference by encouraging more walking.

Barton [10] (p. 182) reported that where jobs and services are located can have direct and indirect effects on unhealthy neighbourhoods, because it can influence how employees travel between home and work. He recommended (ibid.) that, if the goal is to mitigate the negative health effects of private car use, then the "facilities serving a city-wide or regional hinterland-including universities, major hospitals, football stadia and concert halls, as well as major office and retail functions-should be located where there is excellent access by public transport from the whole city, and good inter-city rail services, facilitating inter-city business travel as well as longer distance commuting, shopping and leisure trips". Likewise, wider catchment facilities (e.g., superstores, malls) should be clustered in mixed-use high streets and well served by public transportation (ibid. p. 183). Conversely, large industrial and distribution activities, that employ few people per hectare, where the efficient movement of goods, is of prime importance, should be distanced from residential areas (ibid.). When possible, in a safe manner, mixed use developments encourage jobs and services closer to people and their place of employment and services. This, he suggested, can mitigate the negative effects of sedentary lifestyles by encouraging walking and cycling. 
Furthermore, Gehl [113] wrote extensively about the effect of the quality of urban design on social activities. He suggested that, when the quality of the urban environment is good, optional activities are more likely to occur, which results in more social activities that then mitigate the effects of social isolation. He also recommended mitigating including different uses and active edge zones at street level to encourage people to linger. Likewise, he advised (p. 114) that a gradual transition between public and private spaces encourages people to be in closer contact with life that occurs in public spaces.

\subsection{Decisions about the Location and Spatial Configuration of Housing}

The UKGB [89] reported that the location of housing can contribute to mitigating poor physical and mental health. It advised that the location of housing can affect the frequency of physical activity. Occupants of houses that have direct connections with a diverse range of destinations were said to be more likely to engage in 30 or more minutes of physical activity per day. Additionally, the number of people who exercise for at least three days a week was reported to increase by 25 percent in neighbourhoods that have trails, playgrounds, and parks (ibid.).

The spatial configuration of housing is also said to affect health and wellbeing. For example, Sim [38] stated that a typical European urban block of 4-5 stories has many advantages. He argued that an enclosed block can mitigate the negative health threats of motorized vehicles, social isolation, and safety. He promoted the urban block as offering clearly defined private spaces at the front and back of the building, but also the opportunity for a shared amenity via the common space in the middle of the block. He suggested that this provides residents with privacy when required, but also provides opportunities to socialise with their neighbours if desired. He advocated the design as offering high density at $4-5$ storey scale, depicted as a human scale environment that does not intimidate neighbourhood residents and visitors, while providing increased opportunities (both chance and intentional) for social interaction between residents. He promoted the enclosed block for protecting residents from acoustic noise and air pollution, and for mitigating the negative effects of car traffic. Vehicles have to be kept outside the enclosure to allow for a car-free space on the inside. He argued (ibid., pp. 37-48) that the area inside a block can contain a shared private space and shared public space, giving residents both privacy and opportunities to engage in social interaction. Threats to personal safety are also seen as being mitigated through a protected inner courtyard, a shared location for children to play or store bikes. These benefits are held to be particularly strong for young children who have access to what he described (p. 49) as a "complex courtyard space [that] offers a spectrum of play opportunities with a range of different territories, suitable for different kinds of play at different ages, all accessible without having to go beyond the boundaries of home or to cross a trafficked street". Luckenbill, Subramaniam and Thompson [163] agreed that opportunities for play are essential for young children's healthy physical, social, and emotional development.

\section{Synthesizing Advice on Mental Wellbeing}

London [6] synthesised material presented in the literature to suggest that there are eight key areas of decision making for urban design which are presented as having far-reaching effects on mental wellbeing in neighbourhoods. These eight areas focus on decisions about: limiting emissions and enhancing air quality, greenspace, participation in public life, feeling safe and comfortable, access to peaceful spaces, quality public space, and flexible urban space, shown in Table 3. 
Table 3. Synthesizing advice on mental wellbeing in neighbourhoods (adapted from London 2020, p. 37).

\begin{tabular}{|c|c|c|c|c|c|c|c|}
\hline $\begin{array}{l}\text { Key Physical Health \& } \\
\text { Mental Wellbeing } \\
\text { Detracting Qualities } \\
\text { at the } \\
\text { Neighbourhood Level }\end{array}$ & $\begin{array}{c}\text { Cardio-Vascular } \\
\text { Disease, } \\
\text { Type-2 Diabetes }\end{array}$ & $\begin{array}{l}\text { Poor Diet \& } \\
\text { Food Poverty }\end{array}$ & $\begin{array}{l}\text { Several Forms of } \\
\text { Cancer }\end{array}$ & Respiratory Illnesses & Poor Mental Health & $\begin{array}{c}\text { Vehicle } \\
\text { Related Accidents }\end{array}$ & $\begin{array}{l}\text { Relevant Urban Design } \\
\text { Criteria to } \\
\text { Mitigate UNS }\end{array}$ \\
\hline POOR AIR QUALITY & & & & & & & $\begin{array}{l}\text { Limiting emissions and } \\
\text { sufficient distance of } \\
\text { receptors through } \\
\text { increased gross density } \\
\text { encouraging active } \\
\text { public transportation }\end{array}$ \\
\hline $\begin{array}{c}\text { LITTLE OR NO } \\
\text { ACCESS TO NATURE }\end{array}$ & & & & & & & $\begin{array}{l}\text { Location and network } \\
\text { of greenspace relative to } \\
\text { homes and workplaces }\end{array}$ \\
\hline $\begin{array}{l}\text { LOW PARTICIPATION } \\
\text { IN PUBLIC LIFE }\end{array}$ & & & & & & & $\begin{array}{c}\text { Attractive all-age } \\
\text { friendly design of } \\
\text { walkable public realm. } \\
\text { Active facades and } \\
\text { gradual transition } \\
\text { between public and } \\
\text { private space. } \\
\text { Inclusive and equitable } \\
\text { planning and } \\
\text { design processes. }\end{array}$ \\
\hline $\begin{array}{l}\text { FEELING UNSAFE } \\
\text { \& UNCOMFORTABLE }\end{array}$ & & & & & & & $\begin{array}{l}\text { Safe, well-lit, sociable } \\
\text { space, child-friendliness } \\
\text { and low traffic speeds. }\end{array}$ \\
\hline $\begin{array}{l}\text { LIVING SOMEWHERE } \\
\text { UNHEALTHY }\end{array}$ & & & & & & & $\begin{array}{l}\text { Active travel and } \\
\text { walkable access to daily } \\
\text { needs, including } \\
\text { healthy food options } \\
\text { and primary schools. }\end{array}$ \\
\hline $\begin{array}{l}\text { LIMITED PEACE } \\
\& \text { TRANQULITY }\end{array}$ & & & & & & & $\begin{array}{l}\text { Access to peaceful } \\
\text { places and distance } \\
\text { from sources of } \\
\text { pollution caused by } \\
\text { noise and light. }\end{array}$ \\
\hline $\begin{array}{l}\text { OBESOGENIC } \\
\text { LIFESTYLE }\end{array}$ & & & & & & & $\begin{array}{l}\text { Quality public spaces, } \\
\text { safe walking routes, } \\
\text { connected green spaces } \\
\text { and minimal sprawl. }\end{array}$ \\
\hline $\begin{array}{c}\text { LITTLE (OR NO) } \\
\text { SENSE OF CONTROL } \\
\text { \& IDENTITY }\end{array}$ & & & & & & & $\begin{array}{c}\text { Flexible urban space } \\
\text { that allows for } \\
\text { neighbourhood } \\
\text { modification and } \\
\text { personalization to } \\
\text { express } \\
\text { neighbourhood identity }\end{array}$ \\
\hline
\end{tabular}

Poor air quality, little or no access to nature, low participation in public life, feeling unsafe or uncomfortable, living somewhere unhealthy, limited peace and tranquillity, obesogenic lifestyle, and little (or no) sense of control or identity-all of these components of an unhealthy neighbourhood have to be addressed jointly to tackle the primary and secondary effects described in Part 1 of this paper. If future developments and neighbourhood planning continue in a "business-as-usual mode", the resultant built environment in cities and towns may intensify already existing problems (e.g., increased carbon dioxide emissions from private transport and increase in the number of people with diabetes), thus increasing the likelihood of costly mitigation, and facilitating a decrease in mental wellbeing and quality of life [164] (after, Boyko et al. 2015). Tackling these risks requires simultaneously:

- limiting emissions and sufficient distance of receptors of pollutants through increased gross density encouraging active transportation and public transit

- locating a network of greenspace relative to homes and workplaces

- designing an attractive and walkable public realm, with active facades and a gradual transition between public and private spaces

- $\quad$ providing safe, well-lit, sociable spaces which are child-friendly with low traffic speeds

- $\quad$ enabling active travel and walkable access to daily needs, including healthy food and schools

- $\quad$ offering access to peaceful places and distancing from sources of pollution

- $\quad$ enhancing the quality of public spaces, through safe walking routes and connected green spaces

- $\quad$ employing features that help to express neighbourhood identity, and

- $\quad$ including flexible urban space that can accommodate neighbourhood modifications. 
London [6] suggested none of the urban design criteria required to mitigate "unhealthiness" can deliver quick transformations. However, when harnessed together into an integrated strategy, he pointed to them as making a combined effect that will lead to substantial improvements to people's mental wellbeing and so to their quality of life. These urban design features are intricately linked to the four key areas of urban design decision making shown earlier in Figure 4. Their level of interconnectivity should not be overlooked. The linkages between them speak to the complexity, and the highly integrated nature, of the approach required for attempting to tackle UNS. They must be tackled in an integrated manner when attempting to promote both physical health and mental wellbeing in neighbourhoods.

\section{Discussion}

Conducting this review has been beset with difficulties. First, there is the notion of "neighbourhood" itself. For, as an analytical category, the use of the term "neighbourhood" presumes the existence of what ought to be the matter under investigation-do people who happen to live in some (close) geographical proximity also have some (group-based) sense of shared identity? Additionally, if so, does the latter, in turn, give rise to feelings of neighbourliness? In the literature reviewed, authors slip between these usages, leaving these questions unanswered. As a result, our content analysis has been deprived of a discrete set of categories with which to capture and evaluate the claims being made.

Greater precision for identifying the inclusion and exclusion criteria for the systematic review would have been beneficial to this study by giving it a clearer and more bounded scope. However, this system boundary was difficult to specify at the outset because "the neighbourhood" is not a discrete spatial category. Instead, it proved necessary to review material focused on multiple spatial scales, both above the neighbourhood level, e.g., cities/urban, and below it, e.g., the street. The inclusion of this more broadly based information, not rigidly restricted to investigating health and wellbeing at the neighbourhood scale, could be seen as a methodological limitation. However, in practice, it is also a strength of this study. Since urban design is conceptualised under the umbrella of spatial planning, the review was not constrained to published studies investigating health only at the neighbourhood scale, but could address it at the urban design scale too. Additionally, as both neighbourhood and urban design are fluid terms with varied interpretations, the evidence base for this study draws from a larger pool of literature on the relationship between the built environment and health. This proved useful, since neighbourhoods are seldom completely isolated from each other or from the effect of broader (local to global) economic and environmental threats to their inhabitants' health and wellbeing. However, from a research perspective, what needs to be understood is whether there is a causal relationship between neighbourhood design and occupants' health. As the paper illustrates, it is difficult to make a judgement call on this issue because of the lack or nature of the evidence offered. At its base, the concept of an unhealthy neighbourhood conflates the health of inhabitants with that of their surrounding neighbourhood. This conflation suggests a deterministic and generalised relationship between the two, that is difficult to substantiate since, even where both occur, correlation is not causation.

Our problems were compounded by the nature of the information on which authors base their claims and draw their conclusions about: (a) the relationships between specific characteristics of neighbourhoods and aspects of physical health and mental wellbeing; (b) how urban design can be deployed to address these; and (c) what urban designers should do in the face of such "knowledge". Just what types of evidence base are being called upon here in each of these three cases? Additionally, which disciplines' definition of what constitutes "evidence" prevails in each of them? The relationships of neighbourhood characteristics to health and wellbeing lie within the realms of medical research. Traditionally, this has exacting standards for research design and for the validity of evidence, culminating [165] in the gold standard of properly designed, randomized, and controlled trials. The studies reviewed above that link specific features of urban design to health 
and wellbeing are, where this is reported, based on less exacting standards of research design, frequently depending on case studies for generating generalised advice. However, as Cole and Lorch [166] signalled, the transferability of a preferred design option, from one geographical region to another-let alone from one culture to another-cannot simply be taken for granted. There is, as they reported (p. vii), an unresolved conflict between the appropriateness of built environment practices that are locationally specific and our increasing drift towards the assumption of a globalised (urban design) culture. Calls for a "new professionalism", based on more integrated, interdisciplinary approaches, have an even more problematic basis. For, even if derived from empirical evidence, they are normative, arising from what those making the calls believe should be done for the betterment of society.

From a design perspective, a priority is what designers can and should do on the basis of the available evidence. Here, the paper has signalled a need for humility and caution, to avoid over-claiming what urban designers, operating alone, can deliver. Instead, the aspirations and concerns described above present an enormous challenge, not just to individuals as practitioners, but to their professional bodies as well-how should they act to discharge their responsibility by becoming accountable for their personal and collective roles in delivering healthier outcomes? For urban designers, this means moving beyond simplistic physically led approaches to planning, to embrace the complexity of the interactions between people's health and wellbeing and the built environment in which they live and work. This will require more strategic and holistic methods for making effective decisions. The search for new ways for thinking about, and for delivering, healthier neighbourhoods requires acting on the understanding that they are complex systems. Tackling this complexity, as Gatzweiler et al. [167] advised, requires a coordinated approach, capable of meeting the challenges of the multi-level, multi-sectorial, policymaking that is required to improve urban sustainability, and deal with its attendant concern for healthier outcomes.

Producing healthy neighbourhoods requires, according to Ghaffarianhoseini [15] a rethinking of professional roles. Such a "new professionalism" seen as necessary for unlocking interdisciplinary knowledge could deliver synergistic urban design. Ravetz [168] (p. 48) suggested that, to meet the diverse needs of residents, the "architect may be also a sociologist; the surveyor may be an advocate of local economic development; the landscape designer a food activist". Bridging disciplinary silos to pursue collective goals and responsibilities is seen as being required to build a consensus that health, economic, social, and environmental outcomes are interconnected. Echoing this point, the UK Collaborative Centre for Housing Evidence (p. 4) [169] suggested that a better understanding is "needed into the optimal spatial scales-for example ... neighbourhood scales-for different types of cross professional partnerships". The Centre argued that new administrative groupings are needed, in government and local authorities, to develop integrated strategy across social care, health, transport, and planning agendas, to ensure healthier and resilient homes and neighbourhoods moving forward. This suggests that the core professionals for the built environment are being asked, jointly if not individually, to possess and deploy a very broad range of skills. This would require them to supplement their existing knowledge base of technical domains-in design, planning and engineering-with social competencies required for prompting health and wellbeing outcomes. Here, Ravetz [168] (p. 42) suggested that the goal should not be "to create a perfect urban design template, but to look for ways in which different things might fit together".

Built environment professionals have long held high ambitions about how their skills and expertise can be exercised for the betterment of society [170]. However, designers need to recognise that design alone cannot mitigate UNS. Signalling the limitations of design-led solutions to urban problems is not new [171]. Additionally, while appeals to a "new professionalism" may act as a rallying call, by providing a means to enhance interdisciplinary knowledge and to unlock more synergistic urban design decision-making, we must acknowledge the limitations of such an approach [170-173]. Moreover, it may ascribe too much power and capability to design, as a means of righting social wrongs, and so lead 
urban designers to inadequately confront the structural hindrances that constrain what they can and cannot do.

\section{Conclusions}

As a contribution to conceptualising the more integrated approach to urban design being called for above, this paper offers an overarching framework for representing the component parts that need to be considered to mitigate and prevent the urban design elements seen as leading to unhealthy neighbourhoods. This broadly based framework is set out in Figure 3 above. It illustrates the sheer complexity of what urban designers, and collaborating disciplines, are currently being asked to integrate in their decision making if they are to meet the goal now being set for urban design-delivering healthy neighbourhoods.

The innovative contribution of this paper lies in identification of the wide cluster symptoms used to describe unhealthy neighbourhoods in the literature as being a "syndrome" which needs to be tackled through integrated streams of remedial action. Its significance resides in its acknowledgement that such action needs to draw on experience and expertise that lie beyond that contained by traditional membership of urban design teams. If harnessed and deployed sensitively, and with due regard to the caveats we set out, the use of the term unhealthy neighbourhood "syndrome" could help establish both the more broadly based interventions and the wider skill sets demanded of the teams required to tackle it. Drawing on the extensive review reported above, it is now possible to return to and attempt to answer each of the questions raised at the start of this paper.

(1) Is "the neighbourhood" a useful (spatial) category for analysing, organising, and offering advice to urban designers?

The term "neighbourhood" has long been a ubiquitous feature in literature on planning and urban design [174]. Additionally, as shown by the reviews presented above, it appears consistently in attempts to unravel the effects of the built environment on people's physical health and mental wellbeing. It also has a long history as an organising category employed for marshalling advice on how urban designers are expected to act. However, from a research perspective, the term has multiple shortcomings. First, it is amorphous. It lacks a clearly defined shape or form, and so it is difficult to use to draw a discrete system boundary around what needs to be investigated or from which to draw conclusions. As a result, it offers neither a distinct and unambiguous focus of attention nor a discrete unit of analysis. However, as the contents of this paper amply demonstrate, such flaws have not prevented the proliferation of its use, both in research about, and in guidance for, the design of healthy "neighbourhoods". Just as "neighbourhoods" and "neighbourliness" are common vocabulary amongst those who live in them, so too they are fixed components in both academic discourse and professional practice. Whatever its strengths and weaknesses as a basis for academic inquiry or practical action, the term neighbourhood is firmly implanted. Nor does it have a more discrete or useful rival that is pressing to replace it. As Hodge [175] (p. 298) commented about an adjacent field of inquiry,

"One of the most fundamental steps in geographical research is the creation of meaningful and appropriate spatial units of analysis. In some cases, such units are predefined and logical, but in most instances, geographers (and others) are forced either to use whatever spatial units are available or to construct [those] that make as much sense as possible."

In the absence of a more precise and useful alternative, we will have to work with "the neighbourhood", despite its weaknesses from both research and practice standpoints. However, because of these weaknesses, we need to stay vigilant when we use it. We constantly need to query both its validity and its practical utility whenever we find it convenient to use this term as a basis for making decisions and taking actions.

(2) If so, is it useful to describe a neighbourhood as "healthy" (or indeed "unhealthy")?

Employment of the epithet "healthy" in conjunction with the term "neighbourhood" has becoming widespread, as the literature reviewed above demonstrates. However, 
doing so runs the risk of reification-of treating this ill-defined, social construct as if it were a bounded physical reality, with its own defining characteristics and its own agency. Doing so, in turn, has the attendant danger of ascribing to "the neighbourhood" as a whole causation of both physical and mental symptoms in those who are exposed to it, rather than tracing them back to the particular component parts of the built environment, or the social organisation which this supports, that are associated with them. However, using the term also has an advantage. It can help by redirecting attention away from people who live in neighbourhoods (that are showing disorder, disadvantage, or decline) as being, for instance, feckless or workshy [65]. Its usage can reframe and refocus attention instead on the limiting nature of where people live as (directly or indirectly) contributing to the damaging circumstances of their impoverished existence. Seen from this perspective, those who are underprivileged can be considered not just as economically and socially exploited, but as spatially oppressed as well, confined to live in what they may experience as impoverished and impoverishing environments. Accordingly, this paper cautiously promotes the terms healthy (and unhealthy) neighbourhoods. It does so not as a means of approving or stigmatising one location over another, but rather as offering a lens for paying explicit attention to how urban design may be able to contribute to the alleviation (or reinforcement) of the conditions leading to the health and wellbeing of people in particular locations. The use of the epithet "unhealthy" has traditionally been applied at the neighbourhood scale as have the related terms-disadvantaged, disordered, and declined. However, the word "unhealthy" is not a substitute for these terms, since they have broader, less medicalised, meanings. Nevertheless, the term unhealthy can usefully be adopted as an overarching label signposting all three of these states precisely, because doing so signals a need for meliorative actions that are capable of being effective at this spatial scale.

(3) What is the advantage of labelling the phenomenon of unhealthy neighbourhoods as a "syndrome"?

The component parts of the WHO's definition of a syndrome can be mapped onto what can be discerned in the literature about unhealthy, disadvantaged neighbourhoods. They too display a set of conditions, listed above, that have been identified as occurring within the same time and space. By extension, it does not appear to be unreasonable to label these clusters of conditions as resembling "illnesses" - with the attendant implication that, through the application of the right measures ("medicines"), their symptoms may be alleviated, if not entirely "cured". To the extent that this analogy is accepted, then it may be appropriate to label a neighbourhood as "unhealthy" and the basket of conditions it presents as "unhealthy neighbourhood syndrome". However, it needs to be recognised that this is an analogy. Arguing by analogy implies that because two things are similar, what is true of one is also true of the other [176]. This is a weak form of argumentation that only holds to the extent that the two things are genuinely comparable. In our case, it eventually breaks down, because a neighbourhood is a social construct, not a corporeal being.

However, there is value in employing this analogy. It draws attention to unhealthy neighbourhoods as presenting a tangle of overlapping symptoms, each of which requires precise diagnosis and whose interdependency is part of the condition. This suggests that symptoms cannot simply be treated individually. Dealing with them requires a coordinated programme of integrated treatments. Hence, tackling unhealthy neighbourhoods requires first diagnosing the breadth of issues that need to be dealt with and then sorting these into a longitudinal programme of parallel workstreams containing interdependent activities, which are jointly capable of addressing what needs to be done, in the short-, medium- and long-term future.

(4) Additionally, if UNS is a useful diagnostic label for providing advice, what strategies can be adopted to mitigate the symptoms it is used to diagnose?

The urban design process is highly complicated, involving many actors, engaging with multiple contending forces, with highly intricate interactions between all these. It is this complexity which Figure 5 seeks to depict $[177,178]$. As a result, there is no single 
paramount paradigm around which to organize thought and action in this arena. Additionally, there is certainly no "one-size-fits-all" approach that is likely to be appropriate across the board. Instead, even in one specific location, there are likely to be competing viewpoints about how best to promote health and wellbeing outcomes-and indeed about how much priority should be given to urban design in tackling them. Addressing such complexities requires a nuanced handling of urban design. It points to the need for development of broadly based and coherent strategies and tactics for promoting health and wellbeing-related outcomes, teased out in relation to the specifics of particular built environments. Additionally, the call, outlined above, for a more integrated attack on unhealthy neighbourhoods indicates the need for team-based decision-making involving not just urban designers but also all those middling out actors responsible for an area's economic and social development, as well as for the physical and mental health of its population, see Figure 5. This horizontal and vertical span of collaborative, interdisciplinary engagement is difficult to achieve, let alone sustain, but it will be required to discharge the heavy aspirations that are being placed on interventions in the built environment, particularly once the wider social, economic, environmental, and political changes occurring in cities, towns, and neighbourhoods are taken into account.

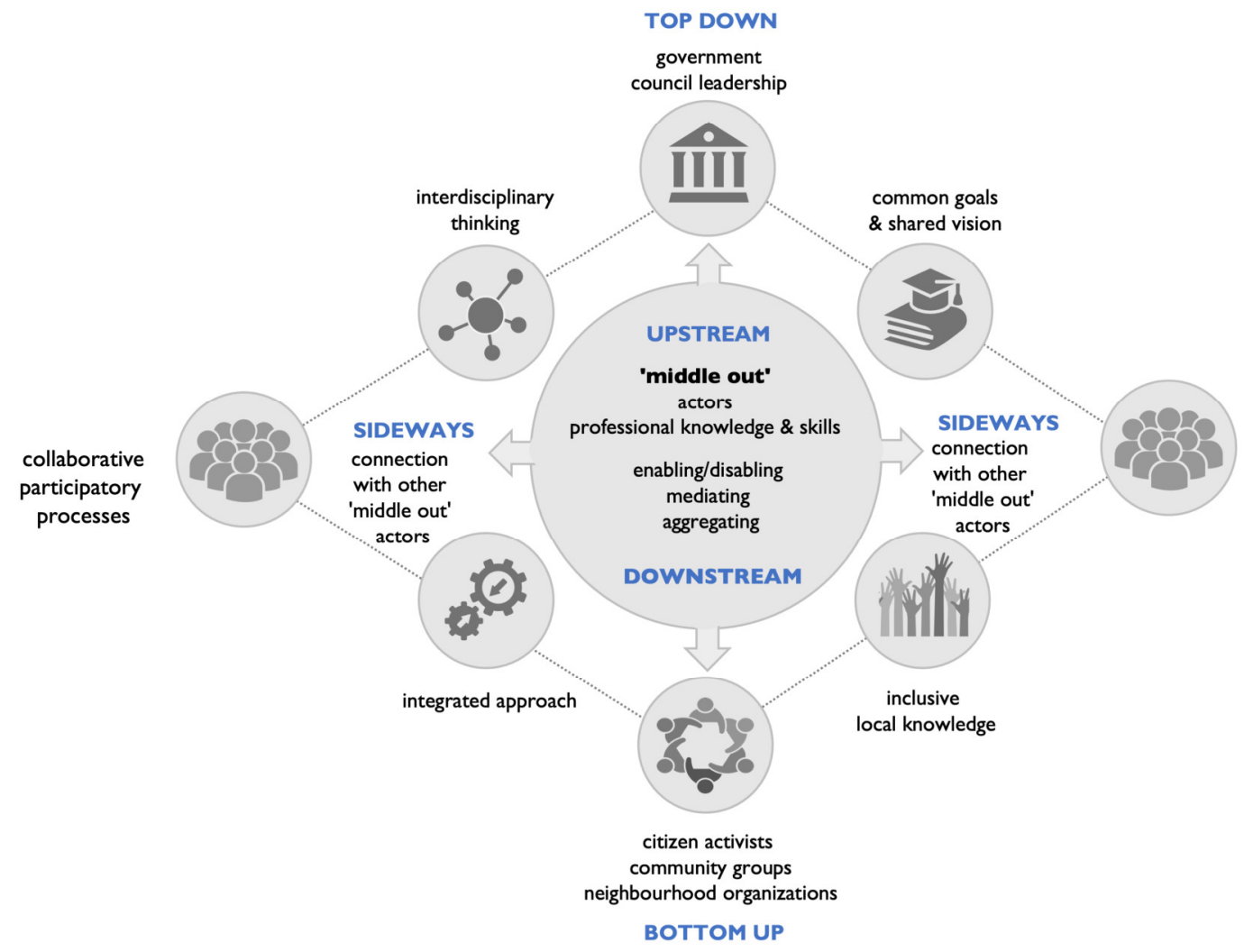

Figure 5. The complexity involved in integrating top-down, middle-out and bottom-up contributions to decision-making (after Janda and Parag 2013; Simpson et al. 2020).

Framing unhealthy neighbourhoods as a "syndrome" helps to identify three steps necessary for tackling it:

1. recognising that such neighbourhoods display an array of symptoms affecting both physical health and mental wellbeing

2. assembling broadly based multi-disciplinary teams with the wide-ranging skills and expertise necessary to address this broad array of symptoms, and

3. deploying these skills through longitudinal programmes of parallel workstreams capable of tackling the particular symptoms presented. 
However, there can be no one-size-fits-all solution. For variations in the context in which interventions are made may require that different symptoms need to be tackled in each. In turn, this means that teams with specifically selected skills and expertise will be required to construct bespoke interventions that have to be implemented through carefully tailored workstreams. However, this will not be sufficient. Even assembling broad horizontal, interdisciplinary, teams of professionals, no matter how inclusive the areas of expertise their disciplines bring together, will not be enough. The level of inclusivity practised will have to extend vertically beyond this as well. It will need to be capable of capturing "the wisdom of the crowd" [179], of collectively marshalling the experience and expertise of disparate groups of political and lay stakeholders, rather than just those of professionals. The methods employed for making decisions will need to align not just the contributions of "middling out" professionals but reconcile these with those of "top down" political actors (who hold the purse strings) and with the "bottom up" aspirations and concerns of those affected when interventions in the built environment are being planned. Achieving the desired outcomes of healthy neighbourhoods cannot rest with a "single set of hands"- however "responsible" or "benign" these may appear. A more inclusive network of shapers and framers, and of affected stakeholders, is required. Together, they have to work with the explicit recognition of the structural constraints on their individual and collective degrees of freedom of action when making locally apposite decisions. As they do so, they also need to recognise that the term "unhealthy neighbourhoods" can often be used as a mask, because decision-makers are unwilling to talk more directly about the poor or about the impoverished nature of the lives of those who have to live within the disadvantaged localities, which their expertise and experience are expected to manage.

Addressing the unequal distribution of resources that could mitigate impoverished neighbourhoods, and the shifts in the deployment of economic resources and political willpower that this would require, lie beyond the scope of this paper. None of the urban design criteria identified above for mitigating UNS can deliver quick transformations. However, harnessed together, integrated strategies for tackling them may be able to make a combined effect that could lead to substantial improvements in health, wellbeing, and so quality of life. The simple act of applying the label "unhealthy neighbour syndrome" is no panacea. However, its use could:

- $\quad$ present a more holistic and inclusive definition of what constitutes unhealthy neighbourhoods, whilst acknowledging the direct and indirect effects of broader economic, environmental forces on desired outcomes in terms of physical health and mental wellbeing;

- $\quad$ expand the evidence bases called upon by urban designers and associated professionals when deciding what contributes to poor physical and mental health, thereby demonstrating critical obstacles as well as signposting future directions;

- help to further demonstrate the economic, social and environmental costs of inadequate neighbourhood urban design and their contribution to poor physical health and mental wellbeing;

- increase both professional and public awareness of the effects of neighbourhood urban design on health and wellbeing;

- $\quad$ lead to developments of incentivized programmes and policies for encouraging politicians, professionals, as well as building owners, to adopt the actions required to move towards healthier neighbourhoods; and

- $\quad$ aid the identification of who are the principal actors, the prime movers, for putting this agenda into practice.

Author Contributions: Conceptualization, H.A. and J.S.; Investigation, H.A. and J.S.; Methodology, H.A.; Visualization, J.S.; Writing-original draft, H.A. and J.S.; Writing-review \& editing, H.A. and I.C. All authors have read and agreed to the published version of the manuscript.

Funding: This research received no external funding. 
Institutional Review Board Statement: Not applicable.

Informed Consent Statement: Not applicable.

Data Availability Statement: Not applicable.

Acknowledgments: The authors would like to thank the editors of Sustainability journal and the three anonymous reviewers for their thoughtful comments on, and constructive contributions to, this article. Additionally, the authors would like to thank Professor Ashraf Salama from University of Strathclyde, and Barbara Illsley, former senior lecturer from University of Dundee, for their critical reviews and technical advices on the earlier versions of this paper.

Conflicts of Interest: The authors declare no conflict of interest.

\section{References}

1. Parker, G.; Salter, K.; Wargent, M. Neighbourhood Planning in Practice; Lund Humphries: London, UK, 2019.

2. AlWaer, H.; Illsley, B. (Eds.) Rethinking Masterplanning: Creating Quality Places; ICE Publishing: London, UK, 2017.

3. AlWaer, H.; Cooper, I. A Review of the Role of Facilitators in Community-Based, Design-Led Planning and Placemaking Events. Built Environ. 2019, 45, 190-211. [CrossRef]

4. AlWaer, H.; Cooper, I. Changing the Focus: Viewing Design-Led Events within Collaborative Planning. Sustainability 2020, 12, 3365. [CrossRef]

5. Husam, A.; Rintoul, S.; Cooper, I. An investigation into decision-making and delivery activities following design-led events in collaborative planning. Archnet-IJAR 2021. [CrossRef]

6. Fred, L. Healthy Placemaking: Wellbeing through Urban Design; RIBA Publishing: London, UK, 2020.

7. Clements-Croome, D. Designing Buildings for People: Sustainable Liveable Architecture; The Crowood Press Ltd.: Wiltshire, UK, 2020.

8. Fainstein, S.S. The just city. Int. J. Urban Sci. 2014, 18, 1-18. [CrossRef]

9. Rudlin, D.; Falk, N. Sustainable Urban Neighbourhood: Building the 21st Century Home; Routledge: Thames, UK, 2009.

10. Barton, H. City of Well-Being: A Radical Guide to Planning; Taylor \& Francis: Thames, UK, 2016.

11. Baker, M.; Hincks, S.; Sherriff, G. Getting involved in plan making: Participation and stakeholder involvement in local and regional spatial strategies in England. Environ. Plan. C Gov. Policy 2010, 28, 574-594. [CrossRef]

12. Pineo, H.; Rydin, Y. Cities, Health and Well-Being; RICS, Parliament Square: London, UK, 2018.

13. Barton, H.; Grant, M.; Guise, R. Shaping Neighbourhoods: For Local Health and Global Sustainability; Routledge: Thames, UK, 2006.

14. Barton, H.; Grant, M. A health map for the local human habitat. J. R. Soc. Promot. Health 2006, 126, 252-253. [CrossRef] [PubMed]

15. Ghaffarianhoseini, A.; AlWaer, H.; Omrany, H.; Alalouch, C.; Clements-Croome, D.; Tookey, J. Sick building syndrome: Are we doing enough? Archit. Sci. Rev. 2018, 61, 99-121. [CrossRef]

16. Pineo, H.; Glonti, K.; Rutter, H.; Zimmermann, N.; Wilkinson, P.; Davies, M. Urban health indicator tools of the physical environment: A systematic review. J. Urban Health 2018, 95, 613-646. [CrossRef]

17. Pinto, A.; Bird, E.; Ige, J.; Burgess-Allen, J.; Pilkington, P. Spatial Planning for Health: An Evidence Resource for Planning and Designing Healthy Places. 2017. Available online: https:/ / www.gov.uk/government/publications/spatial-planning-for-healthevidence-review (accessed on 22 May 2020).

18. Wheaton, B.; Nisenbaum, R.; Glazier, R.H.; Dunn, J.R.; Chambers, C. The neighbourhood effects on health and well-being (NEHW) study. Health Place 2015, 31, 65-74.

19. Douglas, M.; Beautyman, I. Scottish Health and Inequalities Effect Assessment Network. Available online: https://www. improvementservice.org.uk/_data/assets/pdf_file/0021/19740/20-minute-neighbourhood-rapid-scoping-assessment.pdf (accessed on 1 December 2020).

20. Carmona, M. Place value: Place quality and its effect on health, social, economic and environmental outcomes. J. Urban Des. 2019, 24, 1-48. [CrossRef]

21. Maturana, B.; Salama, A.M.; McInneny, A. Architecture, urbanism and health in a post-pandemic virtual world. Archnet-IJAR 2021, 15, 1-9. [CrossRef]

22. Salama, A.M. Coronavirus questions that will not go away: Interrogating urban and socio-spatial implications of COVID-19 measures. Emerald Open Res. 2020, 2, 14. [CrossRef]

23. Royal Town Planning Institute. Enable Healthy Placemaking. 2020. Available online: https://www.rtpi.org.uk/media/5777 / enabling-healthy-placemaking.pdf (accessed on 16 July 2020).

24. Public Health England. Beyond the Data: Understanding the Impact of COVID-19 on BAME Groups. 2020. Available online: https://assets.publishing.service.gov.uk/government/uploads/system/uploads/attachment_data/file/892376/COVID_ stakeholder_engagement_synthesis_beyond_the_data.pdf (accessed on 26 March 2021).

25. Clayton, S.; Manning, C.M.; Hodge, C. Beyond Storms \& Droughts: The Psychological Effects of Climate Change; American Psychological Association and Eco America: Washington, DC, USA, 2014.

26. Moher, D.; Liberati, A.; Tetzlaff, J.; Altman, D.G.; Prisma Group. Preferred reporting items for systematic reviews and metaanalyses: The PRISMA statement. PLoS Med. 2009, 6, e1000097. [CrossRef] [PubMed] 
27. Lupton, R.; Power, A. What We Know about Neighbourhood Change: A Literature Review; CASE Report, (27); Centre for the Analysis of Social Exclusion, London School of Economics and Political Science: London, UK, 2004.

28. The Young Foundation. How Can Neighbourhoods Be Understood and Defined? The Young Foundation: London, UK, 2010.

29. Talen, E. Neighborhood; Oxford University Press: Oxford, UK, 2018.

30. Guise, R.; Webb, J. Characterising Neighbourhoods: Exploring Local Assets of Community Significance; Routledge: Thames, UK, 2017.

31. Mumford, L. The Neighborhood and the Neighborhood Unit. Town Plan. Rev. 1954, 24, 256-270. [CrossRef]

32. Jacobs, J. The Death and Life of Great American Cities; Random House: New York, NY, USA, 1961.

33. Lynch, K. Good City Form; MIT Press: Cambridge, UK, 1984.

34. The Urban Task Force. Towards an Urban Renaissance; Routledge: Thames, UK, 2003.

35. Galster, G. On the nature of neighbourhood. Urban Stud. 2001, 38, 2111-2124. [CrossRef]

36. Barton, H.; Horswell, M.; Millar, P. Neighbourhood accessibility and active travel. In Routledge Handbook of Physical Activity Policy and Practice; Routledge: Thames, UK, 2017; pp. 186-208.

37. Kropf, K. The Handbook of Urban Morphology; John Wiley \& Sons: Hoboken, NJ, USA, 2017.

38. Sim, D. Soft City: Building Density for Everyday Life; Island Press: Washington, DC, USA, 2019.

39. Kleinert, S.; Horton, R. Urban design: An important future force for health and wellbeing. Lancet 2016, 388, 2848-2850. [CrossRef]

40. Scott, M. Covid-19, Place-making and Health. Planning. Theory Pract. 2020, 21, 343-348. [CrossRef]

41. Agrawal, S.; Phillips, D. Catching Up or Falling Behind? Geographical Inequalities in the UK and How They Have Changed in Recent Years; The Institute for Fiscal Studies: London, UK, 2020.

42. Future Place Leadership. Placemaking in the Nordics. Available online: https://mb.cision.com/Public/19081/3120813/972a556 ba01f0b3f.pdf (accessed on 1 December 2020).

43. Ross, C.E.; Mirowsky, J. Neighborhood disadvantage, disorder, and health. J. Health Soc. Behav. 2001, 42, 258-276. [CrossRef] [PubMed]

44. Oakerson, R.J.; Clifton, J.D. The Neighborhood as Commons: Reframing Neighborhood Decline. Fordham URB LJ $2017,44,411$.

45. Kind, A.J.; Buckingham, W.R. Making neighborhood-disadvantage metrics accessible-The neighborhood atlas. N. Engl. J. Med. 2018, 378, 2456. [CrossRef]

46. Durfey, S.N.; Kind, A.J.; Buckingham, W.R.; DuGoff, E.H.; Trivedi, A.N. Neighborhood disadvantage and chronic disease management. Health Serv. Res. 2019, 54, 206-216. [CrossRef] [PubMed]

47. Massey, D.S. The age of extremes: Concentrated affluence and poverty in the twenty-first century. Demography 1996, 33, 395-412. [CrossRef] [PubMed]

48. Jones, K.; Duncan, C. Individuals and their ecologies: Analysing the geography of chronic illness within a multilevel modelling framework. Health Place 1995, 1, 27-40. [CrossRef]

49. LeClere, F.B.; Rogers, R.G.; Peters, K.D. Ethnicity and mortality in the United States: Individual and community correlates. Soc. Forces 1997, 76, 169-198. [CrossRef]

50. Curtice, J.; Ellaway, A.; Robertson, C.; Morris, G.; Allardice, G.; Robertson, R. Public Attitudes and Environmental Justice in Scotland; Scottish Executive Social Research: Edinburgh, UK, 2005.

51. Taylor, R.B.; Covington, J. Community structural change and fear of crime. Soc. Probl. 1993, 40, 374-397. [CrossRef]

52. Swaroop, S.; Krysan, M. The determinants of neighborhood satisfaction: Racial proxy revisited. Demography 2011, 48, 1203-1229. [CrossRef]

53. Zwiers, M.; Bolt, G.; Van Ham, M.; Van Kempen, R. The global financial crisis and neighbourhood decline. Urban Geogr. 2016, 37, 664-684. [CrossRef]

54. Churchman, C.W. Guest Editorial: Wicked Problems. Manag. Sci. 1967, 14, B141-B142. [CrossRef]

55. Andersson, R.; Musterd, S. Area-based policies: A critical appraisal. Tijdschr. Voor Econ. Soc. Geogr. 2005, 96, 377-389. [CrossRef]

56. Van Gent, W.P.; Mustard, S.; Ostendorf, W. Disentangling neighbourhood problems: Area-based interventions in Western European cities. Urban Res. Pract. 2009, 2, 53-67. [CrossRef]

57. Pineo, H.; Zimmermann, N.; Cosgrave, E.; Aldridge, R.W.; Acuto, M.; Rutter, H. Promoting a healthy cities agenda through indicators: Development of a global urban environment and health index. Cities Health 2018, 2, 27-45. [CrossRef]

58. Whitehead, M.; Dahlgren, G. What can be done about inequalities in health? Lancet 1991, 338, 1059-1063. [CrossRef]

59. WHO. A conceptual framework for action on the social determinants of health. In Social Determinants of Health Discussion Paper 2; WHO: Geneva, Switzerland, 2010. Available online: http://www.who.int/social_determinants/final_report/key_concepts_en. pdf?ua=1 (accessed on 27 May 2021).

60. Brundtland, G.H. What is sustainable development. In Our Common Future; The World Commission on Environment and Development (WCED): New York, NY, USA, 1985; Volume 8.

61. National Health Service. Sick Building Syndrome. 2020. Available online: https://www.nhs.uk/conditions/sick-buildingsyndrome/ (accessed on 26 March 2021).

62. WHO. World Health Organization. Indoor Air Pollutants: Exposure and Health Effects. Euro Rep. Stud. 1983, 78, 1-42.

63. Wikipedia. Syndrome. 2021. Available online: https://en.wikipedia.org/wiki/Syndrome (accessed on 21 May 2021).

64. The British Medical Association. The British Medical Association Illustrated Medical Dictionary; Dorling Kindersley: London, UK, 2002.

65. Pascale, C.-M. (Ed.) Social Inequality and the Politics of Representation; Sage: London, UK, 2013.

66. Montgomery, C. Happy City: Transforming Our Lives through Urban Design; Macmillan: New York, NY, USA, 2013. 
67. Beenackers, M.A.; Groeniger, J.O.; Kamphuis, C.B.; Van Lenthe, F.J. Urban population density and mortality in a compact Dutch city: 23-year follow-up of the Dutch GLOBE study. Health Place 2018, 53, 79-85. [CrossRef]

68. Cooper, R.; Boyko, C. The Little Book of Density; Lancaster University: Lancaster, UK, 2012.

69. Barton, H. Land use planning and health and well-being. Land Use Policy 2009, 26, S115-S123. [CrossRef]

70. Frank, L.D.; Andresen, M.A.; Schmid, T.L. Obesity relationships with community design, physical activity, and time spent in cars. Am. J. Prev. Med. 2004, 27, 87-96. [CrossRef]

71. Scottish Land Commission. Vacant and Derelict Land in Scotland Assessing the Effect of Vacant and Derelict Land on Communities. 2019. Available online: https://www.landcommission.gov.scot/downloads/5dd7d4dfa39b6_VDL\%20in\%20Scotland\%20 Final\%20Report\%2020191008.pdf (accessed on 20 November 2020).

72. Lõhmus, M.; Balbus, J. Making green infrastructure healthier infrastructure. Infect. Ecol. Epidemiol. 2015, 5, 30082. [CrossRef]

73. Jones, R.; Yates, G. The built environment and health: An evidence review. In Brief Paper of Glasgow Centre for Population Health; Glasgow Centre for Population Health Publications: Glasgow UK, 2013.

74. Frumkin, H. Urban sprawl and public health. Public Health Rep. 2002, 117, 201-217. [CrossRef]

75. Ewing, R.; Schmid, T.; Killingsworth, R.; Zlot, A.; Raudenbush, S. Relationship between Urban Sprawl and Physical Activity, Obesity, and Morbidity-Update and Refinement. Health Place 2014, 26, 118-126. [CrossRef]

76. Freeman, L. The Effects of Sprawl on Neighborhood Social Ties. J. Am. Plan. Assoc. 2001, 67, 69-77. [CrossRef]

77. Campbell, B.; Zegeer, C.; Huang, H.; Cynecki, M. A Review of Pedestrian Safety Research in the United States and Abroad; Federal Highway Administration: Washington, DC, USA, 2004.

78. Stevenson, M.; Thompson, J.; de Sá, T.H.; Ewing, R.; Mohan, D.; McClure, R.; Roberts, I.; Tiwari, G.; Giles-Corti, B.; Sun, X.; et al. Land use, transport, and population health: Estimating the health benefits of compact cities. Lancet 2016, 388, $2925-2935$. [CrossRef]

79. Gatersleben, B.; Uzzell, D. Affective appraisals of the daily commute: Comparing perceptions of drivers, cyclists, walkers, and users of public transport. Environ. Behav. 2007, 39, 416-431. [CrossRef]

80. Lyons, G.; Chatterjee, K. A human perspective on the daily commute: Costs, benefits and trade-offs. Transp. Rev. 2008, 28, 181-198. [CrossRef]

81. Kageyama, T.; Nishikido, N.; Kobayashi, T.; Kurokawa, Y.; Kaneko, T.; Kabuto, M. Long commuting time, extensive overtime, and sympathodominant state assessed in terms of short-term heart rate variability among male white-collar workers in the Tokyo megalopolis. Ind. Health 1998, 36, 209-217. [CrossRef] [PubMed]

82. Costal, G.; Pickup, L.; Di Martino, V. Commuting-A further stress factor for working people: Evidence from the European Community. Int. Arch. Occup. Environ. Health 1988, 60, 377-385. [CrossRef] [PubMed]

83. White, S.M.; Rotton, J. Type of commute, behavioral aftereffects, and cardiovascular activity: A field experiment. Environ. Behav. 1998, 30, 763-780. [CrossRef]

84. Koslowsky, M.; Kluger, A.N.; Reich, M. Commuting Stress: Causes, Effects, and Methods of Coping; Springer: Berlin, Germany, 2013.

85. Frey, B.; Stutzer, A. The Economics of Happiness. World Econ. 2002, 3, 1-17.

86. Royal Commission on Environmental Pollution (RCEP). The Urban Environment; RCEP: London, UK, 2008.

87. Scottish Government. Scotland's People. In Annual Report: Results from 2012 Scottish Household Survey; Scottish Government: Edinburgh, UK, 2013.

88. Jensen, H.A.; Rasmussen, B.; Ekholm, O. Neighbour noise annoyance is associated with various mental and physical health symptoms: Results from a nationwide study among individuals living in multi-storey housing. BMC Public Health 2019, 19, 1508. [CrossRef] [PubMed]

89. United Kingdom Green Building Council. Health and Wellbeing in Homes. 2016. Available online: https://www.ukgbc org/sites / default/ files / 08453\%20UKGBC\%20Healthy\%20Homes\%20Updated\%2015\%20Aug\%20(spreads).pdf (accessed on 10 August 2020).

90. Department for Environment, Food and Rural Affairs. Improving Air Quality in the UK, Tackling Nitrogen Dioxide in Our Towns and Cities, UK Overview Document, December 2015. Available online: https:/ / assets.publishing.service.gov.uk/government/ uploads/system/uploads/attachment_data/file/486636/aq-plan-2015-overview-document.pdf (accessed on 27 May 2021).

91. Yuchi, W.; Sbihi, H.; Davies, H.; Tamburic, L.; Brauer, M. Road proximity, air pollution, noise, green space and neurologic disease incidence: A population-based cohort study. Environ. Health 2020, 19, 8. [CrossRef]

92. Sustrans. The Role of Active Travel in Improving Health. Toolkit Part 2: Improving Air Quality by Walking and Cycling. 2017. Available online: https://www.sustrans.org.uk/media/4467/improving_air_quality_walking_cyling.pdf (accessed on 27 May 2021).

93. Levinson, A. Valuing public goods using happiness data: The case of air quality. J. Public Econ. 2012, 96, 869-880. [CrossRef]

94. Li, Z.; Folmer, H.; Xue, J. To what extent does air pollution affect happiness? The case of the Jinchuan mining area, China. Ecol. Econ. 2014, 99, 88-99. [CrossRef]

95. Macdonald, C.; Thompson, H. Housing improvement and health: Research findings. In Health Effect Assessment of Housing Improvements: A Guide; Scottish Health and Inequalities Effect Assessment Network: Glasgow, UK, 2013.

96. King, K. Jane Jacobs and 'The Need for Aged Buildings': Neighbourhood Historical Development Pace and Community Social Relations. Urban Stud. 2013, 50, 2407-2424. [CrossRef] 
97. De Kluizenaar, Y.; Roda, C.; Dijkstra, N.E.; Fossati, S.; Mandin, C.; Mihucz, V.G.; Hänninen, O.; Fernandes, E.D.O.; Silva, G.V.; Carrer, P.; et al. Office Characteristics and Dry Eye Complaints in European Workers-The OFFICAIR Study. Build. Environ. 2016, 102, 54-63. [CrossRef]

98. Lim, F.-L.; Hashim, Z.; Said, S.M.; Than, L.T.-L.; Hashim, J.H.; Norbäck, D. Sick Building Syndrome (SBS) among Office Workers in a Malaysian University-Associations with Atopy, Fractional Exhaled Nitric Oxide (FeNO) and the Office Environment. Sci. Total Environ. 2015, 536, 353-361. [CrossRef]

99. Lu, C.; Deng, Q.; Li, Y.; Sundell, J.; Norbäck, D. Outdoor Air Pollution, Meteorological Conditions and Indoor Factors in Dwellings in Relation to Sick Building Syndrome (SBS) Among Adults in China. Sci. Total Environ. 2016, 560-561, 186-196. [CrossRef]

100. Alderman, K.; Turner, L.R.; Tong, S. Floods and human health: A systematic review. Environ. Int. 2012, 47, 37-47. [CrossRef]

101. Foudi, S.; Osés-Eraso, N.; Galarraga, I. The effect of flooding on mental health: Lessons learned for building resilience. Water Resour. Res. 2017, 53, 5831-5844. [CrossRef]

102. Gray, A. Definitions of Crowding and the Effects of Crowding on Health. A Literature Review Prepared for the Ministry of Social Policy; The Ministry of Social Policy: Wellington, New Zealand, 2001.

103. McCrea, R.; Shyy, T.K.; Stimson, R. What is the Strength of the Link Between Objective and Subjective Indicators of Urban Quality of Life? Appl. Res. Qual. Life 2006, 1, 79-96. [CrossRef]

104. Lättman, K.; Olsson, L.E.; Friman, M.; Fujii, S. Perceived Accessibility, Satisfaction with Daily Travel, and Life Satisfaction among the Elderly. Int. J. Environ. Res. Public Health 2019, 16, 4498. [CrossRef] [PubMed]

105. Bjornstrom, E.E.S.; Ralston, M.L. Neighborhood Built Environment, Perceived Danger, and Perceived Social Cohesion. Environ. Behav. 2016, 46, 718-744. [CrossRef]

106. Lindal, P.J.; Hartig, T. Architectural variation, building height, and the restorative quality of urban residential streetscapes. J. Environ. Psychol. 2013, 33, 26-36. [CrossRef]

107. Scopelliti, M.; Carrus, G.; Bonaiuto, M. Is it really nature that restores people? A comparison with historical sites with high restorative potential. Front. Psychol. 2019, 9, 2742. [CrossRef]

108. Garvin, E.; Branas, C.; Keddem, S.; Sellmen, J.; Cannuscio, C. More than just an eyesore: Local insights and solutions on vacant land and urban health. J. Urban Health 2013, 90, 412-426. [CrossRef]

109. Kremer, P.; Hamstead, Z.A.; McPhearson, T. A social-ecological assessment of vacant lots in New York City. Landsc. Urban Plan. 2013, 120, 218-223. [CrossRef]

110. Bond, L.; Kearns, A.; Mason, P.; Tannahill, C.; Egan, M.; Whitely, E. Exploring the relationships between housing, neighbourhoods and mental wellbeing for residents of deprived areas. BMC Public Health 2012, 12, 48. [CrossRef] [PubMed]

111. Jun, H.J.; Hur, M. The relationship between walkability and neighbourhood social environment: The importance of physical and perceived walkability. Appl. Geogr. 2015, 62, 115-124. [CrossRef]

112. Karssenberg, H.; Laven, J.; Glaser, M.; Van't Hoff, M. The city at eye level. In The City at Eye Level: Lessons for Street Plinths; Eburon Academic Publishers: Delft, The Netherlands, 2016; Volume 2, pp. 14-25.

113. Gehl, J. Life between Buildings; Using Public Space: New York, NY, USA, 1987.

114. Corcoran, R.; Marshall, G. From lonely cities to prosocial places: How evidence-informed urban design can reduce the experience of loneliness. In Narratives of Loneliness; Routledge: Thames, UK, 2017; pp. 127-139.

115. Zhang, K.J. Bus Stop Urban Design. Ph.D. Thesis, University of British Columbia, Vancouver, BC, Canada, 2012.

116. Echeverria, S.; Diez-Roux, A.V.; Shea, S.; Borrell, L.N.; Jackson, S. Associations of neighborhood problems and neighborhood social cohesion with mental health and health behaviors: The Multi-Ethnic Study of Atherosclerosis. Health Place 2008, 14, 853-865. [CrossRef] [PubMed]

117. Kim, D. Blues from the neighborhood? Neighborhood characteristics and depression. Epidemiol. Rev. 2008, 30, 101-117. [CrossRef] [PubMed]

118. Zammit, S.; Lewis, G.; Rasbash, J.; Dalman, C.; Gustafsson, E.; Allebeck, P. Individuals, schools and neighbourhood: A multi-level longitudinal study of variation in incidence of psychotic disorders. Arch. Gen. Psychiatry 2010, 67, 914-922. [CrossRef] [PubMed]

119. Auerswald, C.L.; Lin, J.S.; Parriott, A. Six-year mortality in a street-recruited cohort of homeless youth in San Francisco, California. PeerJ 2016, 4, 1909. [CrossRef] [PubMed]

120. Maness, D.L.; Khan, M. Care of the homeless: An overview. Am. Fam. Physician 2014, 89, 634-640.

121. Sandel, M.; Sheward, R.; de Cuba, S.E.; Coleman, S.M.; Frank, D.A.; Chilton, M.; Black, M.; Heeren, T.; Pasquariello, J.; Casey, P.; et al. Unstable housing and caregiver and child health in renter families. Pediatrics 2018, 141, e20172199. [CrossRef] [PubMed]

122. Gehl, J. Cities for People; Island Press: Washington, DC, USA, 2010.

123. Ward, C. The child in the city. Society 1978, 15, 84-91. [CrossRef]

124. Zeiher, H. Shaping Daily Life in Urban Environments. In Children in the City: Home, Neighbourhood and Community; Christensen, P., O'Brien, M., Eds.; Routledge Falmer: London, UK; New York, NY, USA, 2003; pp. 66-81.

125. Christensen, P.; O'Brien, M. Children in the City: Home Neighbourhood and Community; Routledge: Thames, UK, 2003.

126. Manchester, H.; Facer, K. (Re)-Learning the City for Intergenerational Exchange. In Learning the City; Springer: Cham, Switzerland, 2016; pp. 83-98.

127. Vanderbeck, R.; Worth, N. Intergenerational Space; Routledge: Thames, UK, 2015.

128. Van Vliet, W. Intergenerational cities: A framework for policies and programs. J. Intergener. Relatsh. 2011, 9, 348-365. [CrossRef] 
129. Wu, T.; Chan, A. Families, friends, and the neighborhood of older adults: Evidence from public housing in Singapore. J. Aging Res. 2011, 2012, 1-7. [CrossRef]

130. Dickerson, A.E.; Molnar, L.J.; Eby, D.W.; Adler, G.; Bedard, M.; Berg-Weger, M.; Classen, S.; Foley, D.; Horowitz, A.; Kerschner, H.; et al. Transportation and aging: A research agenda for advancing safe mobility. Gerontologist 2007, 47, 578-590. [CrossRef]

131. Sanderson, R.C.; Richards, M.H. The after-school needs and resources of a low-income urban community: Surveying youth and parents for community change. Am. J. Community Psychol. 2010, 45, 430-440. [CrossRef]

132. Baum, F.E.; Ziersch, A.M.; Zhang, G.; Osborne, K. Do perceived neighbourhood cohesion and safety contribute to neighbourhood differences in health? Health Place 2009, 15, 925-934. [CrossRef]

133. Chandola, T. The fear of crime and area differences in health. Health Place 2001, 7, 105-116. [CrossRef]

134. Ziersch, A.M.; Baum, F.E.; Macdougall, C.; Putland, C. Neighbourhood life and social capital: The implications for health. Soc. Sci. Med. 2005, 60, 71-86. [CrossRef]

135. Hale, C. Fear of crime: A review of the literature. Int. Rev. Vict. 1996, 4, 79-150. [CrossRef]

136. Macintyre, S.; Ellaway, A. Ecological approaches: Rediscovering the role of the physical and social environment. In Social Epidemiology; Berkman, L.F., Kawachi, I., Eds.; Oxford University Press: New York, NY, USA, 2000; pp. 332-348.

137. Bennett, G.; McNeill, L.; Wolin, K.; Duncan, D.; Puleo, E.; Emmons, K. Safe to walk? Neighborhood safety and physical activity among public housing residents. PLoS Med. 2007, 4, e306. [CrossRef] [PubMed]

138. Harrison, R.; Gemmell, I.; Heller, R. The population effect of crime and neighbourhood on physical activity: An analysis of 15,461 adults. J. Epidemiol. Community Health 2007, 61, 34-39. [CrossRef] [PubMed]

139. Stronegger, W.J.; Titze, S.; Oja, P. Perceived characteristics of the neighborhood and its association with physical activity behavior and self-rated health. Health Place 2010, 16, 736-743. [CrossRef] [PubMed]

140. Stokols, D.; Shumaker, S.A. The Psychological Context of Residential Mobility and Weil-Being. J. Soc. Issues 1982, 38, $149-171$. [CrossRef]

141. D'Souza, R.M.; Strazdins, L.; Clements, M.S.; Broom, D.H.; Parslow, R.; Rodgers, B. The health effects of jobs: Status, working conditions, or both? Aust. N. Z. J. Public Health 2005, 29, 222-228. [CrossRef] [PubMed]

142. Kershaw, K.N.; Mezuk, B.; Abdou, C.M.; Rafferty, J.A.; Jackson, J.S. Socioeconomic position, health behaviors, and C-reactive protein: A moderated-mediation analysis. Health Psychol. 2010, 29, 307-316. [CrossRef] [PubMed]

143. Stowe, R.P.; Peek, M.K.; Perez, N.A.; Yetman, D.L.; Cutchin, M.P.; Goodwin, J.S. Herpesvirus reactivation and socioeconomic position: A community-based study. J. Epidemiol. Community Health 2010, 64, 666-671. [CrossRef]

144. Hajrasouliha, A.; Del Rio, V.; Francis, J.; Edmondson, J. Urban form and mental wellbeing: Scoping a theoretical framework for action. J. Urban Spaces Ment. Health 2018, 5. Available online: https:/ /www.semanticscholar.org/paper/Urban-form-andmental-wellbeing\%3A-scoping-a-for-Hajrasouliha-Rio/85b21cdf4fa0a04a43c2db78ba6bdc3ccdce4177\#paper-header (accessed on 27 May 2021).

145. Talen, E.; Koschinsky, J. Compact, walkable, diverse neighborhoods: Assessing effects on residents. Hous. Policy Debate 2014, 24, 717-750. [CrossRef]

146. Zhang, X.; Holt, J.B.; Lu, H.; Onufrak, S.; Yang, J.; French, S.P.; Sui, D.Z. Neighborhood commuting environment and obesity in the United States: An urban-rural stratified multilevel analysis. Prev. Med. 2014, 59, 31-36. [CrossRef] [PubMed]

147. White, M.P.; Elliott, L.R.; Taylor, T.; Wheeler, B.W.; Spencer, A.; Bone, A.; Depledge, M.H.; Fleming, L.E. Recreational physical activity in natural environments and implications for health: A population based cross-sectional study in England. Prev. Med. 2016, 91, 383-388. [CrossRef]

148. Ding, D.; Lawson, K.D.; Kolbe-Alexander, T.L.; Finkelstein, E.A.; Katzmarzyk, P.T.; Van Mechelen, W.; Pratt, M. Lancet Physical Activity Series 2 Executive Committee. The economic burden of physical inactivity: A global analysis of major non-communicable diseases. Lancet 2013, 388, 1311-1324. [CrossRef]

149. Ogen, Y. Assessing nitrogen dioxide $\left(\mathrm{NO}_{2}\right)$ levels as a contributing factor to the coronavirus (COVID-19) fatality rate. Sci. Total Environ. 2020, 726, 138605. [CrossRef]

150. Ulmer, J.M.; Wolf, K.L.; Backman, D.R.; Tretheway, R.L.; Blain, C.J.; O’Neil-Dunne, J.P.; Frank, L.D. Multiple Health Benefits of Urban Tree Canopy: The Mounting Evidence for a Green Prescription. Health Place 2016, 42, 54-62. [CrossRef] [PubMed]

151. Liu, H.; Li, F.; Li, J.; Zhang, Y. The relationships between urban parks, residents' physical activity, and mental health benefits: A case study from Beijing, China. J. Environ. Manag. 2017, 190, 223-230. [CrossRef]

152. Wilson, E. Biophilia; Harvard University Press: Cambridge, MA, USA, 1984.

153. Kaplan, R.; Kaplan, S. The Experience of Nature: A Psychological Perspective; CUP Archive: Cambridge, UK, 1989.

154. Ulrich, R.S. Natural versus urban scenes: Some psychophysiological effects. Environ. Behav. 1981, 13, 523-556. [CrossRef]

155. Roe, J.; Aspinall, P. The restorative outcomes of forest school and conventional school in young people with good and poor behaviour. Urban For. Urban Green. 2011, 10, 205-212. [CrossRef]

156. Burton, E.; Mitchell, L.; Stride, C. Bed of roses? The role of garden space in older people's well-being. Proc. Inst. Civ. Eng.-Urban Des. Plan. 2015, 168, 164-173. [CrossRef]

157. Velarde, M.D.; Fry, G.; Tveit, M. Health effects of viewing landscapes-Landscape types in environmental psychology. Urban For. Urban Green. 2007, 6, 199-212. [CrossRef]

158. Kaplan, R. The nature of the view from home: Psychological benefits. Environ. Behav. 2001, 33, 507-542. [CrossRef] 
159. Lohr, V.I.; Pearson-Mims, C.H. Responses to scenes with spreading, rounded, and conical tree forms. Environ. Behav. 2006, 38, 667-688. [CrossRef]

160. Benzeval, M.; Bond, L.; Campbell, M.; Egan, M.; Lorenc, T.; Petticrew, M.; Popham, F. How does Money Influence Health? In Improving Access to Greenspace: A New Review for 2020; PHE Publications; Public Health England: London, UK, 2020; pp. 1-112.

161. National Health Service. Exercise Health Benefits. 2020. Available online: https://www.nhs.uk/live-well/exercise/exercisehealth-benefits / (accessed on 10 August 2020).

162. Sinnett, D.; Chatterjee, K.; Williams, K.; Cavill, N. Creating built environments that promote walking and health: A review of international evidence. J. Dep. Plan. Archit. 2012, 4, 38-44.

163. Luckenbill, J.; Subramaniam, A.; Thompson, J. This Is Play: Environments and Interactions that Engage Infants and Toddlers; National Association for the Education of Young Children: Washington, DC, USA, 2020. Available online: https:/ / public.ebookcentral. proquest.com/choice/publicfullrecord.aspx?p=5968834 (accessed on 27 May 2021).

164. Boyko, C.T.; Cooper, R.; Cooper, C. Measures to assess well-being in low-carbon-dioxide cities. Proc. Inst. Civ. Eng.-Urban Des. Plan. 2015, 168, 185-195. [CrossRef]

165. Harris, R.; Helfand, S.; Woolf, K.; Lohr, C.; Mulrow, S.; Teutsch, S.; Atkins, D. Current methods of the US Preventative Services Task Force: A review of the process. Am. J. Prev. Med. 2001, 20, 21-35. [CrossRef]

166. Cole, R.; Lorch, R. (Eds.) Buildings, Culture and Environment: Informing Local and Global Practices; Blackwell Publishing: Oxford, UK, 2003.

167. Gatzweiler, F.; Corburn, J.; Moran Flores, E.; Fuders, F.; Howden-Chapman, P.; Ke, X.; Rozenblat, C.; Wang, L.; Sun, W.; Zhang, Y. The Little Book of the Health of Cities; Cooper, R., Coulton, C., Eds.; Imagination Lancaster: Lancaster, UK, 2019; ISBN 978-1-86220-368-6.

168. Ravetz, J. Master planning by and for the urban shared mind: Towards a 'neighbourhood 3.0'. In Placemaking: Rethinking the Master Planning Process; Al Waer, H., Illsley, B., Eds.; ICE Publishing: London, UK, 2017; pp. 39-55.

169. United Kingdom Collaborative Centre for Housing Evidence. 2020. Available online: https://housingevidence.ac.uk/ publications / effect-of-housing-design-and-placemaking-on-social-value-and-wellbeing-in-the-pandemic-interim-report/ (accessed on 10 August 2020).

170. AlWaer, H.; Cooper, I. Built environment professionals and the call for a 'new' professionalism. In Rethinking Masterplanning: Creating Quality Places; AlWaer, H., Illsley, B., Eds.; ICE Publishing: London, UK, 2017; pp. 209-221.

171. Cooper, I. Inadequate grounds for a 'design-led' approach to urban renaissance? Build. Res. Inf. 2000, 28, 212-219. [CrossRef]

172. Cole, R.J. Navigating Climate Change: Rethinking the Role of Buildings. Sustainability 2020, 12, 9527. [CrossRef]

173. Hill, S.; Lorenz, D. Rethinking professionalism: Guardianship of land and resources. Build. Res. Inf. 2011, 39, 314-319. [CrossRef]

174. Talen, E. Plan vs. Process: The Case of Neighbourhood Planning. Built Environ. 2019, 45, 173-189. [CrossRef]

175. Hodge, D.C. Defining Spatial Units in Geographic Research. Prof. Geogr. 1996, 48, 298. [CrossRef]

176. Lau, J.; Chan, J. Analogical arguments, Critical Thinking Web, Hong Kong University. 2021. Available online: https://philosophy. hku.hk/think/arg/analogy.php (accessed on 27 May 2021).

177. Janda, K.; Parag, Y. A middle-out approach for improving energy performance in buildings. Build. Res. Inf. 2013, 41, 39-50. [CrossRef]

178. Simpson, K.; Janda, K.B.; Owen, A. Preparing 'middle actors' to deliver zero-carbon building transitions. Build. Cities 2020, 1, 610-624. [CrossRef]

179. Almaatouq, A.; Noriega-Campero, A.; Alotaibi, A.; Krafft, P.; Moussaid, M.; Pentland, A. Adaptive social networks promote the wisdom of crowds. Proc. Natl. Acad. Sci. USA 2020, 117, 11379-11386. [CrossRef] [PubMed] 